\title{
A!
}

This is an electronic reprint of the original article.

This reprint may differ from the original in pagination and typographic detail.

Koskinen, Ari M.P.; Karisalmi, Kaisa

\section{Polyketide stereotetrads in natural products}

Published in:

Chemical Society Reviews

DOI:

$10.1039 / b 417466 f$

Published: 01/01/2005

Document Version

Peer reviewed version

Please cite the original version:

Koskinen, A. M. P., \& Karisalmi, K. (2005). Polyketide stereotetrads in natural products. Chemical Society Reviews, 34, 677-690. https://doi.org/10.1039/b417466f

This material is protected by copyright and other intellectual property rights, and duplication or sale of all or part of any of the repository collections is not permitted, except that material may be duplicated by you for your research use or educational purposes in electronic or print form. You must obtain permission for any other use. Electronic or print copies may not be offered, whether for sale or otherwise to anyone who is not an authorised user. 


\title{
Polyketide stereotetrads in natural products
}

\author{
Ari M. P. Koskinen and Kaisa Karisalmi
}

DOI: $10.1039 / b 417466 f$

Natural products (or secondary metabolites) remain as the most important source for discovery of new and potential drug molecules. With high resolution data of their structures, and the advancement of synthesis possibilities, analysis of the natural products based on their specific structural features is valuable to those entering the field. In this tutorial review we attempt such an analysis indicating the salient features of the structural classes with examples of the synthesis of each one of them. As the particular class of natural products, we have chosen polyketides.

\section{Introduction}

Polyketides form an enormous class of natural products synthesized by bacteria, fungi and plants through a condensation reaction of simple carboxylic acids. ${ }^{1}$ Polyketides vary widely in structure; they can be cyclic, acyclic, small, large, simple or complex (Fig. 1). They may also be linked to different sugars or aminosugars. It is quite clear that because polyketides vary so much in structure, they also have many different biological activities. Between 5000 and 10000 polyketides are known and about $1 \%$ of them possess drug activity, which is five times as many as the average in natural products. ${ }^{2}$ Pharmaceutically important polyketide drugs include antibiotics, cancer chemotherapeutics, cholesterol lowering agents and antifungals.

Polyketides can be grouped into smaller subgroups: fatty acids, polypropionates and aromatic polyketides. ${ }^{3}$ Polypropionates are furthermore divided in three groups:

Laboratory of Organic Chemistry, Helsinki University of Technology, PO Box 6100, FIN-02015 TKK, Finland. polyether antibiotics, macrolides and spiroketals. These subgroups have structural similarities within each group, but there are also several structural features, which are universal among all polyketides.

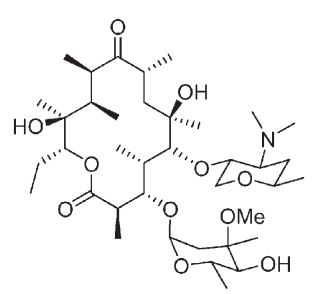

Erythromycin A

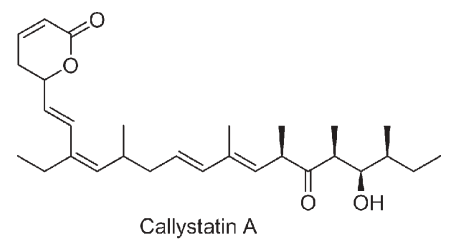

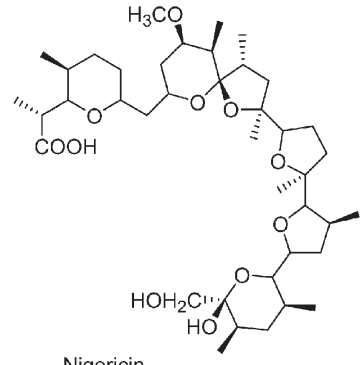

Nigericin

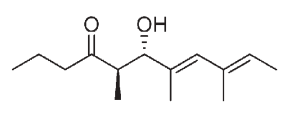

Pteroenone
Fig. 1 Examples of naturally occurring polyketides.

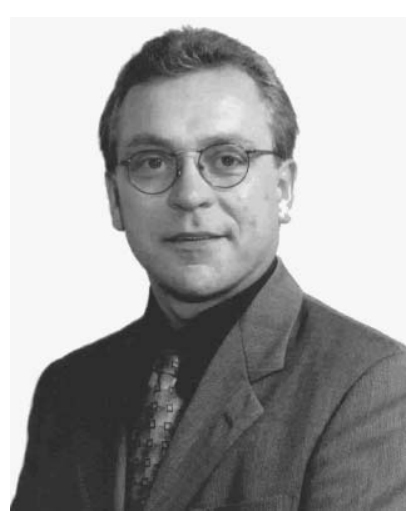

Ari M. P. Koskinen
Professor Ari M. P. Koskinen was born in Hyvinkää, Finland in 1956 and received his Doctor of Technology in 1983. After postdoctoral studies at the University of California, Berkeley, he joined the University of Surrey, England, as a lecturer in 1989. He moved to the University of Oulu, Finland in 1992 as Professor of Chemistry, and transferred to his current position at the Helsinki University of Technology in August, 1999 as Professor of Organic Chemistry. Prof. Koskinen has been a member of the Finnish Academy of Sciences and Letters since 2003, and a member of the Novartis Foundation International Scientific Advisory Panel since 2004.

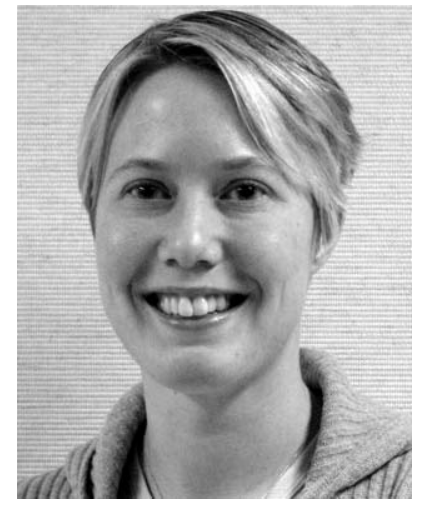

Kaisa Karisalmi
Kaisa Karisalmi was born in Helsinki, Finland, in 1975. She started her studies at the University of Helsinki and received an $M S c$ in organic chemistry in 2000. In the same year she joined the research group of Professor Ari Koskinen at the Helsinki University of Technology as a PhD student. Her PhD work focused on asymmetric synthesis of natural products. After receiving her PhD in 2004 she started to work at Karyon as a manager of organic synthesis. 
<smiles>[R]C(O)=C(C)[C@@H](O)C([R1])C</smiles>

Fig. 2 General structure of a stereotetrad.

The stereotetrad (Fig. 2) is a common substructure in polyketides. Four stereogenic centers, next to each other, result in eight possible diastereomeric combinations of this structure (Fig. 3): anti, anti, anti (1a); anti, anti, syn (1b); anti, syn, anti (1c); syn, anti, anti (1d); syn, syn, anti (1e); syn, anti, syn (1f); anti, syn, syn (1g) and syn, syn, syn (1h).

Polyketides containing a fragment like $\mathbf{1 a - 1 d}$ and $\mathbf{1 f}-\mathbf{1 h}$ are abundant in nature. These natural products are challenging target molecules for synthetic chemists; particularly stereocontrol in the synthesis of stereotetrads shown in Fig. 3 calls for accurate planning and realization in the laboratory.

The stereotetrad 1e proved to be a very uncommon structure in natural products. A literature search (Scifinder, Beilstein) returned several hits for this syn, syn, anti stereotetrad, but no polyketide with this fragment was found.

\section{Stereotetrads in natural products}

\section{1 anti, anti, anti}

2.1.1 Ionomycin. The polyether antibiotic ionomycin (Fig. 4) was isolated 1978 from the fermentation broths of Streptomyces congoblatus and its structure, including absolute stereochemistry, was resolved one year later. As an ionophore, ionomycin chelates various inorganic cations and transports them across lipid membranes. This character, especially its high affinity for $\mathrm{Ca}^{2+}$ ions, has made it an important molecule in neurochemistry research. ${ }^{4}$

Three total syntheses of ionomycin have been published; Evans (1990), ${ }^{5}$ Hanessian (1990) ${ }^{6}$ and Lautens (2002), ${ }^{7}$ each<smiles>[R]C(C)C(C)C(O)C([R])C</smiles>
1a<smiles>[R]C(C)C(O)C(C)C([R])O</smiles>
1e<smiles>[R]C(O)C(C)[C@H](O)C([R])C</smiles>
$1 \mathrm{~b}$<smiles>[R]C(C)C(O)[C@@H](C)[C@H](C)O</smiles>
$1 \mathrm{f}$<smiles>[R]C(C)[C@H](C)[C@@H](O)[C@H](C)O</smiles><smiles>[R]C(C)[C@@H](C)[C@@H](O)[C@H](C)O</smiles>

$1 \mathrm{~g}$<smiles>[R]C(C)C(O)[C@@H](C)[C@@H](C)O</smiles><smiles>[R]C(C)[C@H](C)[C@@H](O)[C@H]([R2])[13CH3]</smiles>

Fig. 3

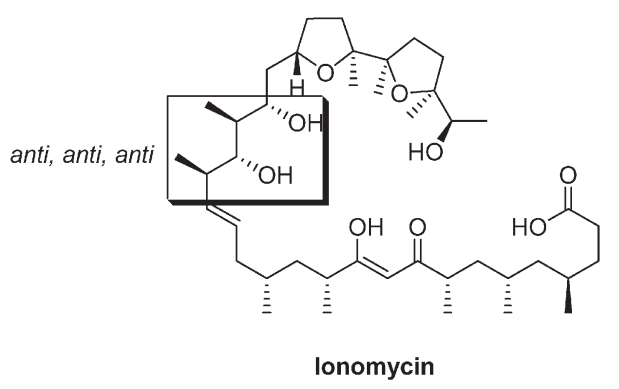

Fig. 4 with different strategies for the synthesis of the anti, anti, anti dipropionate fragment (boxed in Fig. 4).

Hanessian et al. based the synthesis of the stereotetrad fragment on L-glutamic acid as the chiral progenitor (Scheme 1). ${ }^{8}$ Glutamic acid was first converted to the butyrolactone derivative 2 , with a sequence involving deamination, lactonisation, oxidation and conjugate addition. The lactone was then treated with KHMDS, and the resulting enolate was oxygenated with oxodiperoxymolybdenum pyridine to produce the hydroxy lactone 3 . The trisubstituted lactone was then opened and converted to the acyclic diol 4, which was selectively protected and converted to the epoxide $\mathbf{5}$. The epoxide 5 was enlarged to the unsaturated lactone $\mathbf{6}$ by selenoacetate extension oxidation. Then a second conjugate addition was conducted followed by an oxygenation step leading to a 1 : 1.7 mixture of epimeric alcohols 7 and 8 , the minor epimer 7 being the desired one. Lactone 7 was reduced, the primary alcohol $\mathbf{9}$ was protected as the pivalate ester $\mathbf{1 0}$, followed by ketal formation, deesterification and Swern oxidation. The major epimer $\mathbf{8}$ was subjected to the same protocol as 7 to afford the thermodynamically less stable aldehyde 13. Aldehyde 13 was equilibrated to the desired aldehyde $\mathbf{1 1 .}$

Evans et al. published the total synthesis of ionomycin also in $1990,{ }^{5}$ based on the chiral auxiliary strategy (oxazolidinone) for creating the first asymmetric centers (Scheme 2). Aldol addition of the boryl enolate derived from crotonimide $\mathbf{1 4}$ with aldehyde $\mathbf{1 5}$ provided the crystalline syn, $\alpha$-vinyl adduct $\mathbf{1 6}$. The chiral auxiliary was reductively removed to give the corresponding alcohol 17. Deoxygenation was then achieved by tosylation and hydride reduction to produce the stereotriad 19. After $\mathrm{OsO}_{4}$ oxidation of the double bond two epimeric alcohols 20a,b were obtained in a $78: 22$ ratio. Selective TBDPS protection of the primary alcohol, followed by ketal formation and removal of the TBDPS group, produced two separable diastereomeric alcohols 23 and $\mathbf{2 4}$. The major diastereomer $\mathbf{2 3}$ was directly oxidized to the desired aldehyde 25. The minor diastereomer $\mathbf{2 4}$ was also oxidized, followed by base mediated epimerization to produce the thermodynamically more stable aldehyde $\mathbf{2 5}$.

The most recent total synthesis of ionomycin has been published in 2002 by Lautens et al. ${ }^{7}$ Their synthesis was based on the ring-opening methodology, which had been developed earlier in their laboratory. The synthesis of the dipropionate fragment began with the [3.2.1] oxabicyclic alkene 27, which was reductively opened to give the substituted cycloheptene $\mathbf{2 8}$ in excellent yield (95\%) and enantioselectivity (93-95\% ee) (Scheme 3). One stereocenter in $\mathbf{2 8}$ needed inversion for achieving the desired stereochemistry ( $\operatorname{step} b$ ). Cycloheptene 29 was then opened ozonolytically and reductive work-up produced the diol 30. The primary hydroxyl groups were differentiated with the help of PMP-acetal formation and finally the free hydroxyl group was oxidized by the Swern protocol producing the desired building block 33 with the correct stereochemistry.

2.1.2 Calyculin C. Calyculins form a class of highly cytotoxic metabolites originally isolated from the marine sponge 

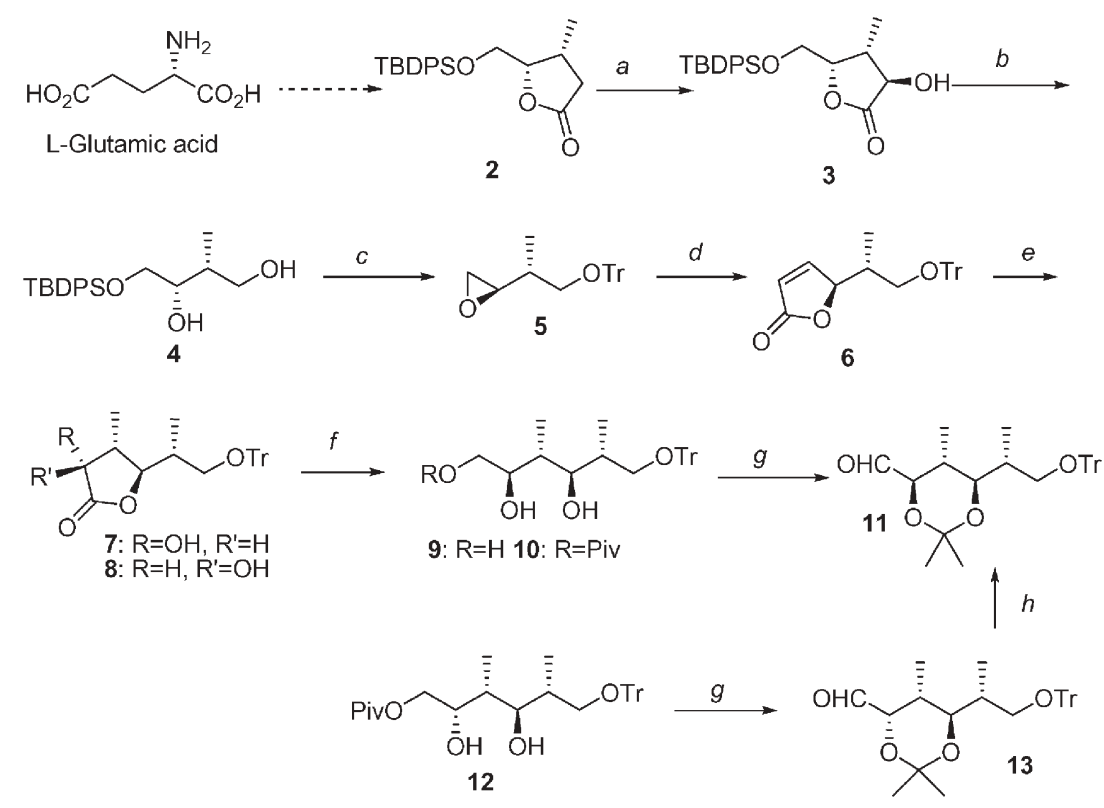

Scheme $1 a$ KHMDS, MoOPH, THF, $-78{ }^{\circ} \mathrm{C} \rightarrow-30{ }^{\circ} \mathrm{C}, 78 \% ; b 1 . \mathrm{NaBH}_{4}$, aq. THF; 2. $\mathrm{NaIO}_{4}$, aq. $\mathrm{MeOH} ;$ then $\mathrm{NaBH}_{4} ; c 1 . \mathrm{TrCl}, \mathrm{Et}_{3} \mathrm{~N}$, DMAP, $\mathrm{CH}_{2} \mathrm{Cl}_{2} ; 2$. $\mathrm{MsCl}, \mathrm{Et}_{3} \mathrm{~N}, \mathrm{CH}_{2} \mathrm{Cl}_{2}$, then $n$ - $\mathrm{Bu}_{4} \mathrm{NF}$, THF; $d$ 1. $\mathrm{PhSeCH}_{2} \mathrm{CO}_{2} \mathrm{H}, \mathrm{BuLi} ; 2$. EDAC $\cdot \mathrm{HCl}, \mathrm{DMAP} ; 3.30 \% \mathrm{H}_{2} \mathrm{O}_{2}, \mathrm{CH}_{2} \mathrm{Cl}_{2} ; e 1 . \mathrm{CuI}$, $\mathrm{MeLi} \cdot \mathrm{LiBr}$, ether, $-20{ }^{\circ} \mathrm{C} ; 2$. KHMDS, THF, $-78{ }^{\circ} \mathrm{C} \rightarrow-30{ }^{\circ} \mathrm{C}, \mathrm{MoOPH} ; f 1$. $\mathrm{LiAlH}_{4}$, THF; 2. pivaloyl chloride, pyridine; $g$ 1. camphorsulfonic acid, acetone, 2,2-dimethoxypropane; 2. $\mathrm{LiAlH}_{4}$, THF; 3. oxalyl chloride, DMSO, $\mathrm{CH}_{2} \mathrm{Cl}_{2},-78{ }^{\circ} \mathrm{C} \rightarrow-30{ }^{\circ} \mathrm{C} ; h \mathrm{~K}_{2} \mathrm{CO}_{3}, \mathrm{MeOH}^{\circ}$

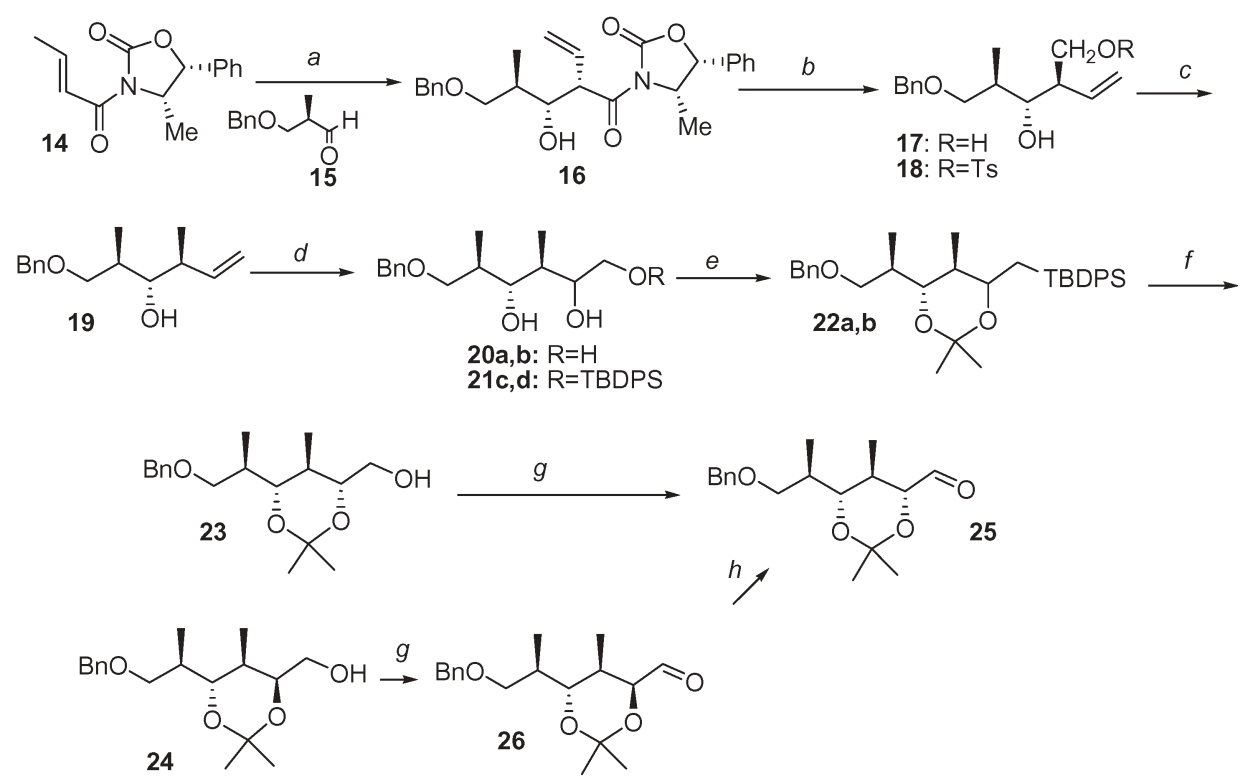

Scheme $2 a \mathrm{Bu}_{2} \mathrm{BOTf}, \mathrm{Et}_{3} \mathrm{~N}, \mathrm{CH}_{2} \mathrm{Cl}_{2},-78{ }^{\circ} \mathrm{C}, \mathbf{1 5},-78{ }^{\circ} \mathrm{C}, \mathrm{H}_{2} \mathrm{O}_{2}, \mathrm{MeOH} ; b 1 . \mathrm{Bu}_{3} \mathrm{~B}, \mathrm{HOAc}, \mathrm{THF} ; 2 . \mathrm{LiBH}_{4}, \mathrm{THF}, 0{ }^{\circ} \mathrm{C} ; 3 . \mathrm{H}_{2} \mathrm{O}_{2}, \mathrm{MeOH} c 1$. $p$-TolSO ${ }_{2} \mathrm{Cl}$, pyridine, $5{ }^{\circ} \mathrm{C}$; 2. $\mathrm{Li}(\mathrm{Et})_{3} \mathrm{BH}$, THF; 3. $\mathrm{H}_{2} \mathrm{O}_{2}, \mathrm{NaOH}(\mathrm{aq}), \mathrm{MeOH} ; d 1$. OsO $\mathrm{O}_{4}, \mathrm{R}_{3} \mathrm{~N}-\mathrm{O}, \mathrm{H}_{2} \mathrm{O} / \mathrm{Me}_{2} \mathrm{CO} ; 2$. TBDPSCl, Et 3 N, DMAP, $\mathrm{CH}_{2} \mathrm{Cl}_{2} ; e \mathrm{Me}_{2} \mathrm{C}(\mathrm{OMe})_{2}, \mathrm{CSA}$, acetone; $f(n-\mathrm{Bu})_{4} \mathrm{NF}$, THF; $g \mathrm{Pyr} \cdot \mathrm{SO}_{3}, \mathrm{Et}_{3} \mathrm{~N}$, DMSO; $h \mathrm{~K}_{2} \mathrm{CO}_{3}, \mathrm{MeOH}$.

Discodermia calyx. Calyculins have proven to be strong serine/ threonine protein phosphatase inhibitors. ${ }^{8}$

The $\mathrm{C}_{9}-\mathrm{C}_{19}$ dipropionate lactone fragment of calyculin $\mathrm{C}$ (boxed in Fig. 5) contains seven of the total fifteen stereogenic centers and is thereby a key substructure of this sponge metabolite. Synthetic efforts towards calyculins have been recently reviewed. ${ }^{9}$ Several syntheses of the lactone-dipropionate fragment have been published with varying strategies. ${ }^{10}$ The $\mathrm{C}_{9}-\mathrm{C}_{19}$ fragment is an anti, anti, anti stereotetrad, which can be reached either by linear or by convergent approaches.

In our own work, we adopted a linear approach for the construction of the anti, anti, anti stereotetrad. First, a short and highly enantio- and diastereoselective synthesis of the key intermediate $\mathbf{4 3}$ was realised (Scheme 4). ${ }^{11}$

The remaining steps for the $\mathrm{C}_{9}-\mathrm{C}_{19}$ fragment of Calyculin $\mathrm{C}$ are shown in Scheme 5. ${ }^{12}$ The lactone aldehyde $\mathbf{4 3}$ was first allowed to react with a chiral crotyl borane reagent 44 yielding 


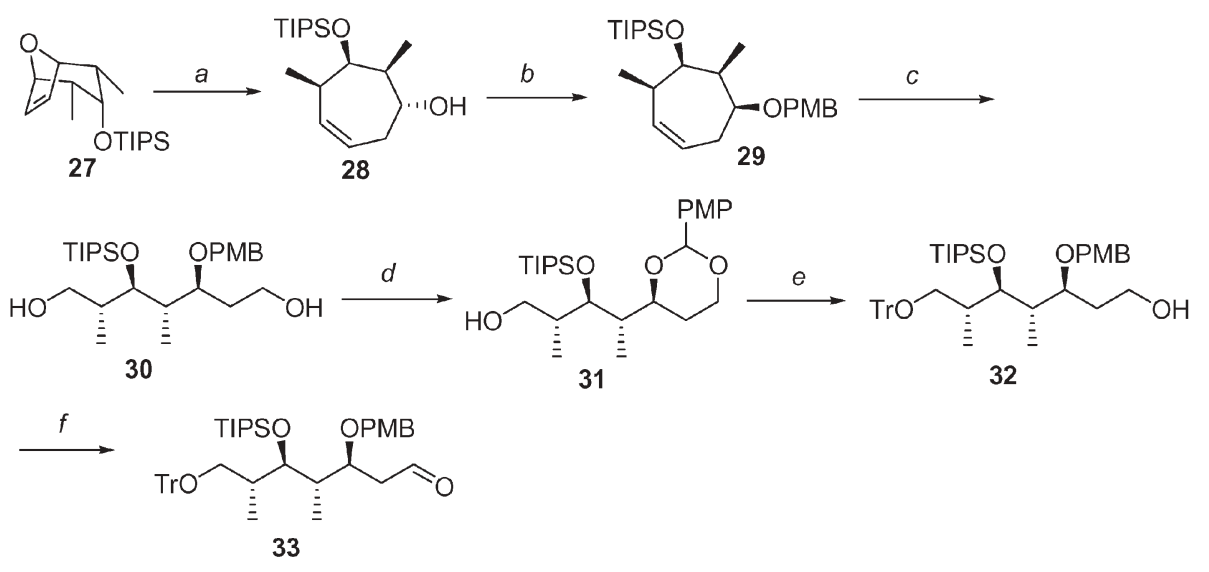

Scheme $3 a \mathrm{Ni}(\mathrm{COD})_{2},(S)$-BINAP, toluene, $65{ }^{\circ} \mathrm{C}$, DIBAL-H (added over $20 \mathrm{~h}$ ); $b$ 1. DMSO, $(\mathrm{COCl})_{2}, \mathrm{NEt}_{3}, \mathrm{CH}_{2} \mathrm{Cl}_{2},-78{ }^{\circ} \mathrm{C} ; 2$. toluene, DIBAL-H, $-78{ }^{\circ} \mathrm{C}$; 3. THF, KHMDS, PMBCl; $c \mathrm{O}_{3}, \mathrm{MeOH} / \mathrm{CH}_{2} \mathrm{Cl}_{2},-78{ }^{\circ} \mathrm{C}$ then $\mathrm{NaBH}_{4}, \mathrm{rt} ; d \mathrm{CH}_{2} \mathrm{Cl}_{2}, \mathrm{DDQ}$, mol. sieves; $e$ 1. TrCl, Et $3 \mathrm{~N}$, DMAP, $\mathrm{CH}_{2} \mathrm{Cl}_{2} ; 2 . \mathrm{CH}_{2} \mathrm{Cl}_{2}$, DIBAL-H, $-78{ }^{\circ} \mathrm{C}->0{ }^{\circ} \mathrm{C} ; f$ DMSO, $(\mathrm{COCl})_{2}, \mathrm{NEt}_{3}, \mathrm{CH}_{2} \mathrm{Cl}_{2},-78{ }^{\circ} \mathrm{C}$.

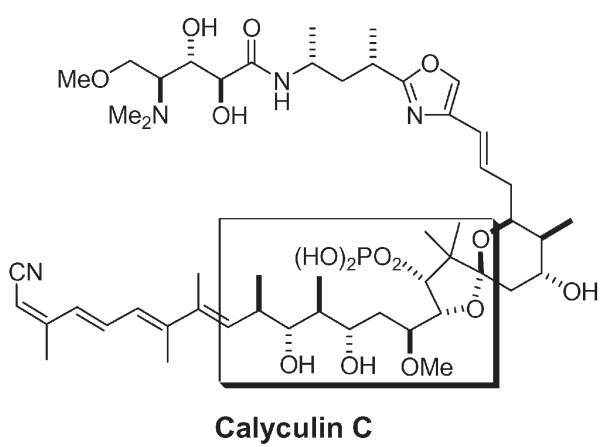

Fig. 5

a $6: 1$ diastereomeric mixture of two anti homoallylic alcohols. The major diastereomer $\mathbf{4 5}$ was isolated with simple flash chromatography, followed by ozonolysis to yield the unstable $\beta$-hydroxy aldehyde 46. The second crotylation was realized with Z-crotyl trifluorosilane, giving a single diastereomer 47. Finally the diol was converted to the corresponding ketal $\mathbf{4 8}$.

\section{2 anti, anti, syn and anti, syn, anti: Aplyronines A/B/C}

Aplyronines A, B and C (Fig. 6), 24-membered cytotoxic marine macrolides, were isolated from the sea hare Aplysia kurodai in 1993.

Aplyronines contain three stereotetrads: one with anti, syn, anti and two with anti, anti, syn stereochemistries. Yamada published the first total synthesis of Aplyronine A in 1996, only three years after the isolation. ${ }^{13}$ Their retrosynthetic analysis revealed each of the three stereotetrads to represent an individual substructure in the total synthesis.

The synthesis of the anti, syn, anti stereotetrad (Scheme 6) began with an Evans aldol reaction between 49 and 15 in which two new stereogenic centers were created. The fourth stereocenter was introduced successfully through Sharpless asymmetric epoxidation (step $d$ ). The final stages in the

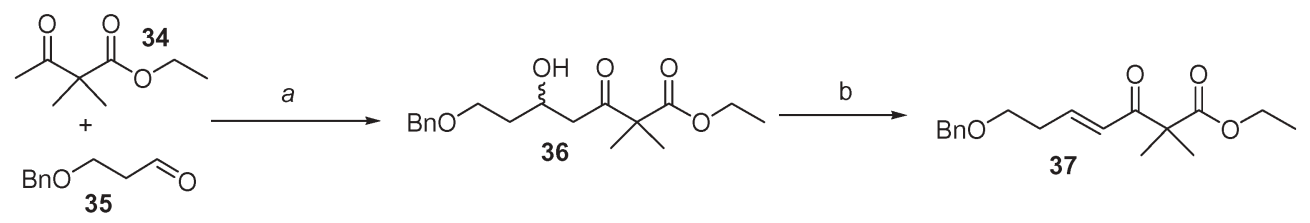<smiles>COC(=O)O[C@H](CCOBr)[C@@H](CCOBr)OC</smiles>

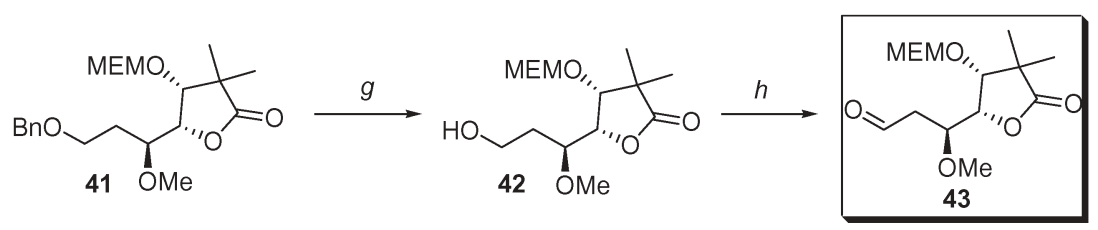

Scheme $4 a$ LDA, the ketone 34, 1 h., then the aldehyde 35, THF, $-78{ }^{\circ} \mathrm{C}, 1 \mathrm{~h} ; b \mathrm{MsCl}_{,} \mathrm{NEt}_{3}, \mathrm{CH}_{2} \mathrm{Cl}_{2} 0{ }^{\circ} \mathrm{C}, 4.5 \mathrm{~h} ; c(\mathrm{DHQD})_{2} \mathrm{PYR}, \mathrm{K} \mathrm{Fe}(\mathrm{CN})_{6}$, $\mathrm{K}_{2} \mathrm{CO}_{3}, \mathrm{NaHCO}_{3}, \mathrm{MeSO}_{2} \mathrm{NH}_{2}, \mathrm{OsO}_{4}, \mathrm{H}_{2} \mathrm{O} / t$ - $\mathrm{BuOH} 0{ }^{\circ} \mathrm{C}, 17 \mathrm{~h} ; d \mathrm{MeI}, \mathrm{Ag}_{2} \mathrm{O}, \mathrm{Et}{ }_{2} \mathrm{O}$, reflux, $22 \mathrm{~h} ; e$ LS-Selectride, THF, $-78{ }^{\circ} \mathrm{C}, 15 \mathrm{~min} ; f \mathrm{MEMCl}$, DIPEA, $\mathrm{CH}_{2} \mathrm{Cl}_{2}$, reflux, $48 \mathrm{~h} ; \mathrm{g} \mathrm{Pd}(\mathrm{OH})_{2} / \mathrm{C}, \mathrm{EtOH}, \mathrm{H}_{2}, 40 \mathrm{~min} ; h \mathrm{TPAP}, \mathrm{CH}_{2} \mathrm{Cl}_{2}, 4 \AA \mathrm{MS}, 2 \mathrm{~h}$. 


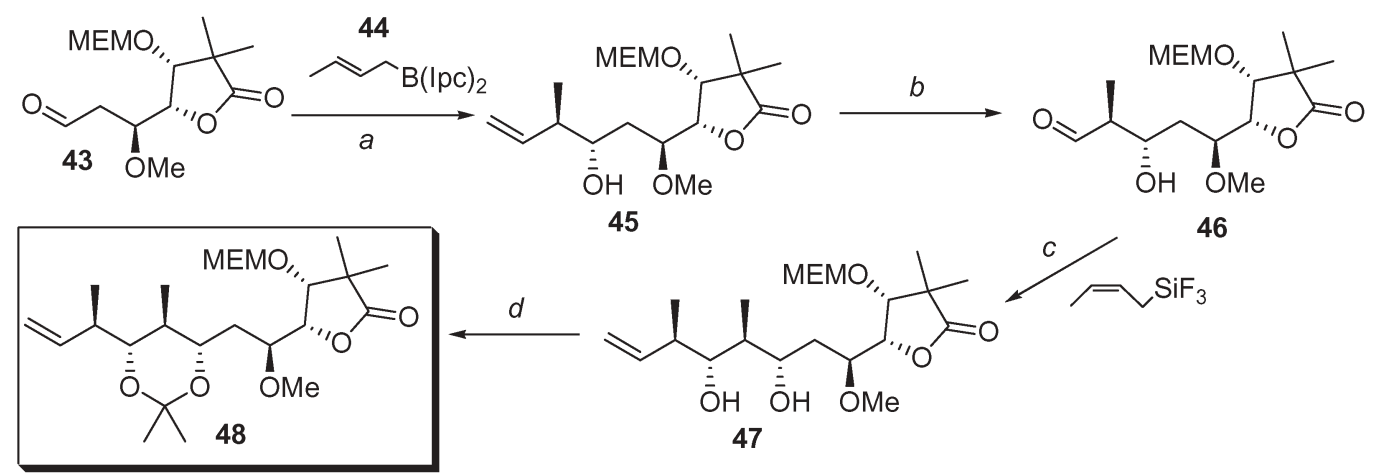

Scheme $5 a$ the crotyl reagent was prepared from (+)-IpcBOMe and trans-butene in THF at $-78{ }^{\circ} \mathrm{C}$, then $\mathrm{BF} \cdot{ }_{3} \cdot \mathrm{OEt}$, the aldehyde $43,-78{ }^{\circ} \mathrm{C}, 1 \mathrm{~h}$,

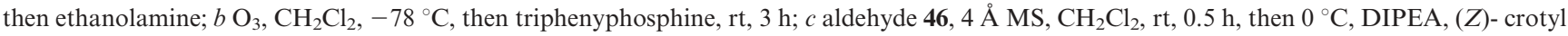
trifluorosilane, $4 \mathrm{~h}$; $d$ 2-methoxy propene, pyridinium $p$-toluenesulfonate (PPTS) (cat.), $\mathrm{CH}_{2} \mathrm{Cl}_{2}, \mathrm{rt}, 0.5 \mathrm{~h}$.

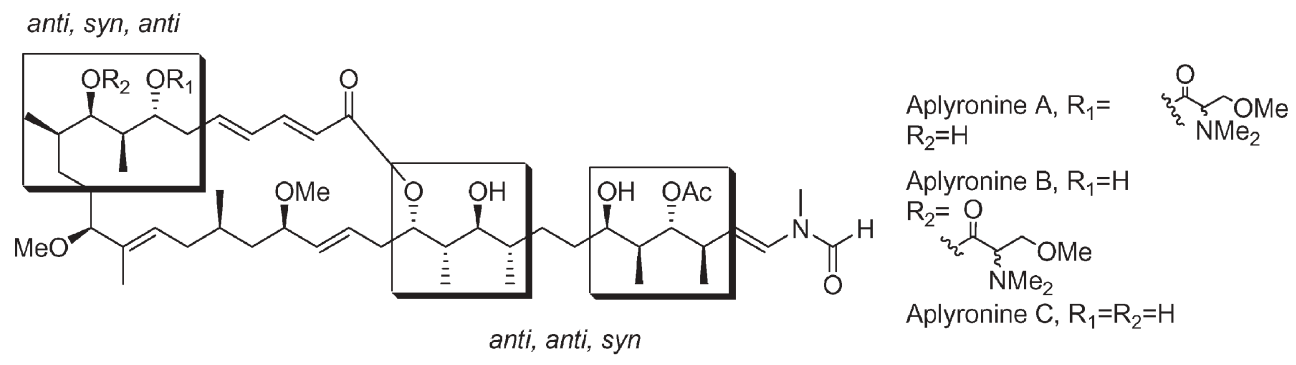

Fig. 6

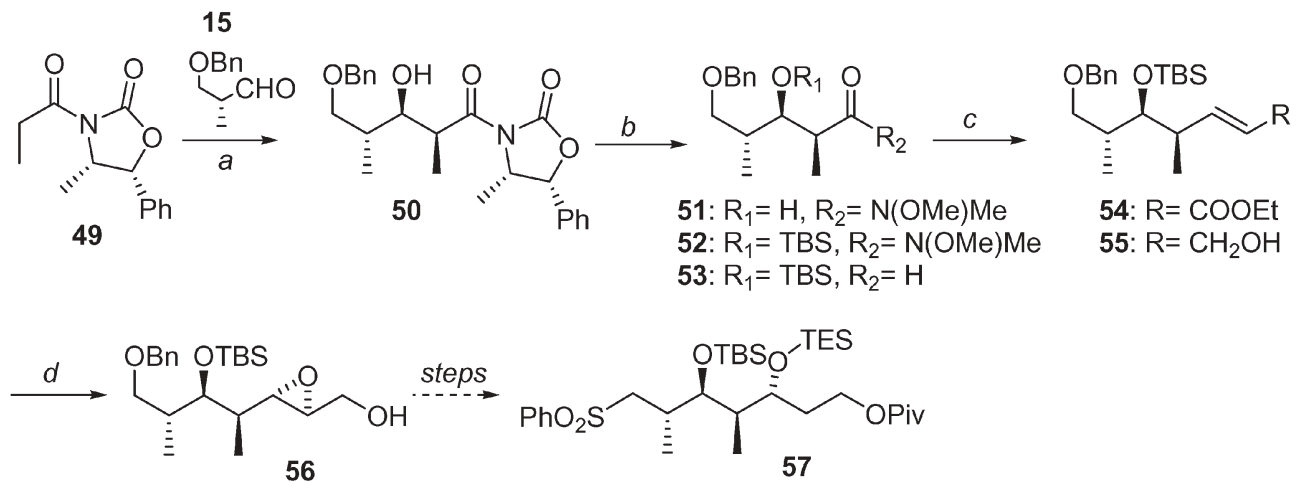

Scheme $6 a \mathrm{Bu}_{2} \mathrm{BOTf}, \mathrm{Et}_{3} \mathrm{~N}, \mathrm{CH}_{2} \mathrm{Cl}_{2}, 0{ }^{\circ} \mathrm{C}$, then $15,-78{ }^{\circ} \mathrm{C}, 3 \mathrm{~h}->0{ }^{\circ} \mathrm{C}, 20 \mathrm{~min} ; b 1 . \mathrm{Me}_{3} \mathrm{Al}, \mathrm{MeONHMe} \cdot \mathrm{HCl}, \mathrm{THF}$, toluene, $\mathrm{CH}_{2} \mathrm{Cl}{ }_{2},-10$ to $>0{ }^{\circ} \mathrm{C}, 1.6 \mathrm{~h} ; 2 . t$-BuMe $2 \mathrm{SiOTf}, 2,6$-lutidine, $\mathrm{CH}_{2} \mathrm{Cl}_{2}, 0{ }^{\circ} \mathrm{C}, 1 \mathrm{~h}$; 3. DIBAL-H, THF, hexane, $-78{ }^{\circ} \mathrm{C}, 2 \mathrm{~h} ; c 1$. $(i \text {-PrO })_{2} \mathrm{P}(\mathrm{O}) \mathrm{CH}{ }_{2} \mathrm{COOEt}, t$-BuOK, THF, $-78{ }^{\circ} \mathrm{C}, 1 \mathrm{~h}$ to $>0{ }^{\circ} \mathrm{C}, 1.5 \mathrm{~h} ; 2$. DIBAL-H, $\mathrm{CH}_{2} \mathrm{Cl}_{2}$, hexane, $-78{ }^{\circ} \mathrm{C}, 1 \mathrm{~h} ; d \mathrm{Ti}(\mathrm{O}-i \text {-Pr })_{4},(+)$-DET, $t$-BuOOH, $4 \AA \mathrm{MS}^{-} \mathrm{CH}_{2} \mathrm{Cl}{ }_{2},-23{ }^{\circ} \mathrm{C}, 1 \mathrm{~h}$.

synthesis included protection of the hydroxyl groups and conversion of the leftward hydroxyl group to the sulfone $\mathbf{5 7 .}$

The syntheses of the C(21)-C(27) (Scheme 7) and C(28)$\mathrm{C}(34)$ anti, anti, syn, stereotetrads were both also based on the Evans aldol chemistry and the Sharpless asymmetric epoxidation. The fourth stereogenic center was created through nucleophilic attack of methylcuprate onto the epoxide 66 to produce the desired anti, anti, syn stereochemistry.

Paterson et al. have also been working on the synthesis of aplyronines. ${ }^{14}$ Although their total synthesis of aplyronines is still incomplete, the syntheses of the stereotetrad subunits have been published.

The synthesis of the anti, syn, anti stereotetrad began with an aldol reaction between the $E$-boron enolate of the chiral precursor 68 and aldehyde 69 (Scheme 8). The desired anti, anti aldol product $\mathbf{7 0}$ was obtained with high diastereoselection ( $\leqslant 97 \% \mathrm{ds}$ ). The ketone was then reduced in a 1,3-anti manner to produce the desired anti, syn, anti stereochemistry in $\mathbf{7 1}$.

Paterson et al. also completed the synthesis of the $\mathrm{C}(21)$ C(34) subunit of aplyronines. ${ }^{14}$ This southern segment contains two anti, anti, syn stereotetrads and the syntheses of both fragments were based on the chiral starting materials (72, 73, 76), diastereoselective aldol reactions (steps $a$ and $c$ ) and stereoselective 1,3-anti diol reduction (steps $d$ and $g$ ) (Scheme 9).

Synthetic methodology developed in the laboratory of Marshall suited perfectly for the synthesis of the stereotetrads of aplyronines. ${ }^{15}$ The key step in the syntheses of the anti, syn, 
<smiles>CCC(=O)N1C(=O)OC(c2ccccc2)[C@@H]1C</smiles><smiles>C[C@H](C(=O)N1C(=O)O[C@H](c2ccccc2)[C@H]1C)[C@@H](O)CCOCc1ccccc1</smiles>

60

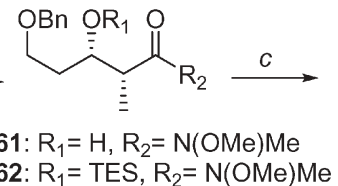

62: $R_{1}=$ TES, $R_{2}=N(O M e) M e$

63: $\mathrm{R}_{1}=\mathrm{TES}, \mathrm{R}_{2}=\mathrm{H}$

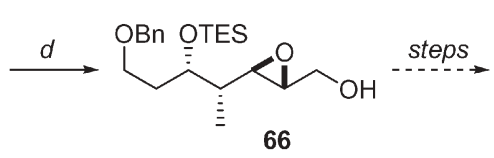

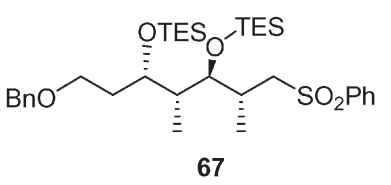

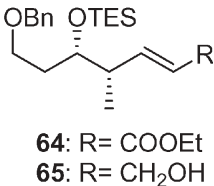

65: $\mathrm{R}=\mathrm{CH}_{2} \mathrm{OH}$

Scheme $7 a \mathrm{Bu}_{2} \mathrm{BOTf}, \mathrm{Et}_{3} \mathrm{~N}, \mathrm{CH}_{2} \mathrm{Cl}_{2}, 0{ }^{\circ} \mathrm{C}$, then $\mathbf{5 9},-78{ }^{\circ} \mathrm{C}, 2 \mathrm{~h}$ to $>0{ }^{\circ} \mathrm{C}, 2 \mathrm{~h} ; b 1 . \mathrm{Me}_{3} \mathrm{Al}, \mathrm{MeONHMe} \cdot \mathrm{HCl}, \mathrm{THF}$, toluene, $\mathrm{CH}_{2} \mathrm{Cl}{ }_{2},-10$ to $>0{ }^{\circ} \mathrm{C}, 1.5 \mathrm{~h} ; 2$. TESCl, imidazole, DMF, $23{ }^{\circ} \mathrm{C}, 35 \mathrm{~min} ; 3$. DIBAL-H, THF, hexane, $-78{ }^{\circ} \mathrm{C}, 2 \mathrm{~h} ; c 1 .(i-\mathrm{PrO}){ }_{2} \mathrm{P}(\mathrm{O}) \mathrm{CH}{ }_{2} \mathrm{COOEt}, t-\mathrm{BuOK}, \mathrm{THF}$, $-78{ }^{\circ} \mathrm{C}, 1.5 \mathrm{~h}$ to $>0{ }^{\circ} \mathrm{C}, 1.5 \mathrm{~h} ; 2$. DIBAL-H, $\mathrm{CH}_{2} \mathrm{Cl}_{2}$, hexane, $-78{ }^{\circ} \mathrm{C}, 1.5 \mathrm{~h} ; d \mathrm{Ti}(\mathrm{O}-i \text {-Pr })_{4},(-)-\mathrm{DET}, t$-BuOOH$, 4 \AA \mathrm{MS}^{-} \mathrm{CH}_{2} \mathrm{Cl}{ }_{2},-23{ }^{\circ} \mathrm{C}, 2 \mathrm{~h}$.

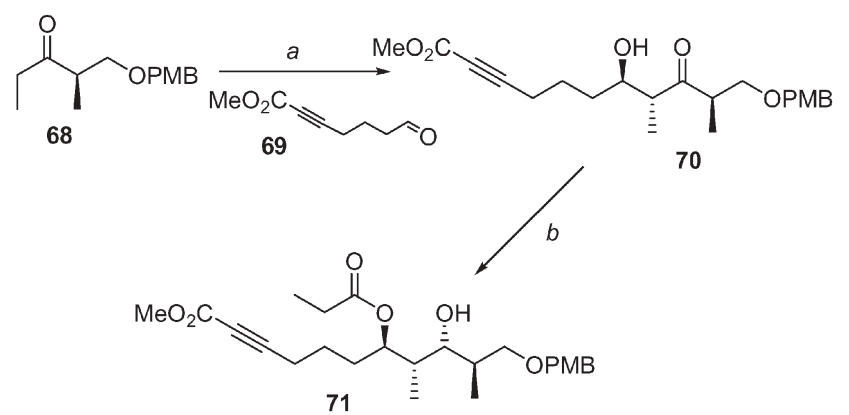

Scheme $8 a(\mathrm{c}-\mathrm{Hex})_{2} \mathrm{BCl}, \mathrm{Et}_{3} \mathrm{~N}, \mathrm{Et}_{2} \mathrm{O}, 0{ }^{\circ} \mathrm{C}, 1 \mathrm{~h}$, then $-78{ }^{\circ} \mathrm{C}$ and 69 to $>-20{ }^{\circ} \mathrm{C}, 12 \mathrm{~h}$, oxidative work-up; $b \mathrm{SmI}_{2}$, EtCHO, THF, $0{ }^{\circ} \mathrm{C}$, $15 \mathrm{~min}$, then $\mathbf{7 0}, 0^{\circ} \mathrm{C}, 2 \mathrm{~h}$.

anti (Scheme 10) and both anti, anti, syn (Scheme 11) stereotetrads was the first reaction; an in situ prepared chiral allenylindium reagent reacted with a chiral $\alpha$-methyl aldehyde
(Scheme 10, step $a$; Scheme 11, steps $a$ and $c$ ) creating two new stereogenic centers with high diastereoselectivity. ${ }^{16}$ The fourth stereocenter of the stereotetrads was created either via Sharpless asymmetric epoxidation (Scheme 10, step b; Scheme 11, step $d$ ) or by aldol reaction (Scheme 11, step $b$ ). In the synthesis of the rightward anti, anti, syn stereotetrad, the aldol reaction (Scheme 11, step $d$ ) produced two separable diastereomers 95 and 96 in a $60: 40$ ratio. The desired diastereomer 96 proved to be the minor one, but the major diastereomer 95 was inverted to the desired diastereomer 96 and elaborated to the intermediate $\mathbf{1 0 0}$.

\section{3 syn, anti, anti: Amphotericin B/Amphoteronolide B}

The antifungal macrolide antibiotic amphotericin B (Fig. 7) was isolated from Streptomyces nodosus in 1956 and its stereochemical structure was resolved 15 years later by X-ray analysis.

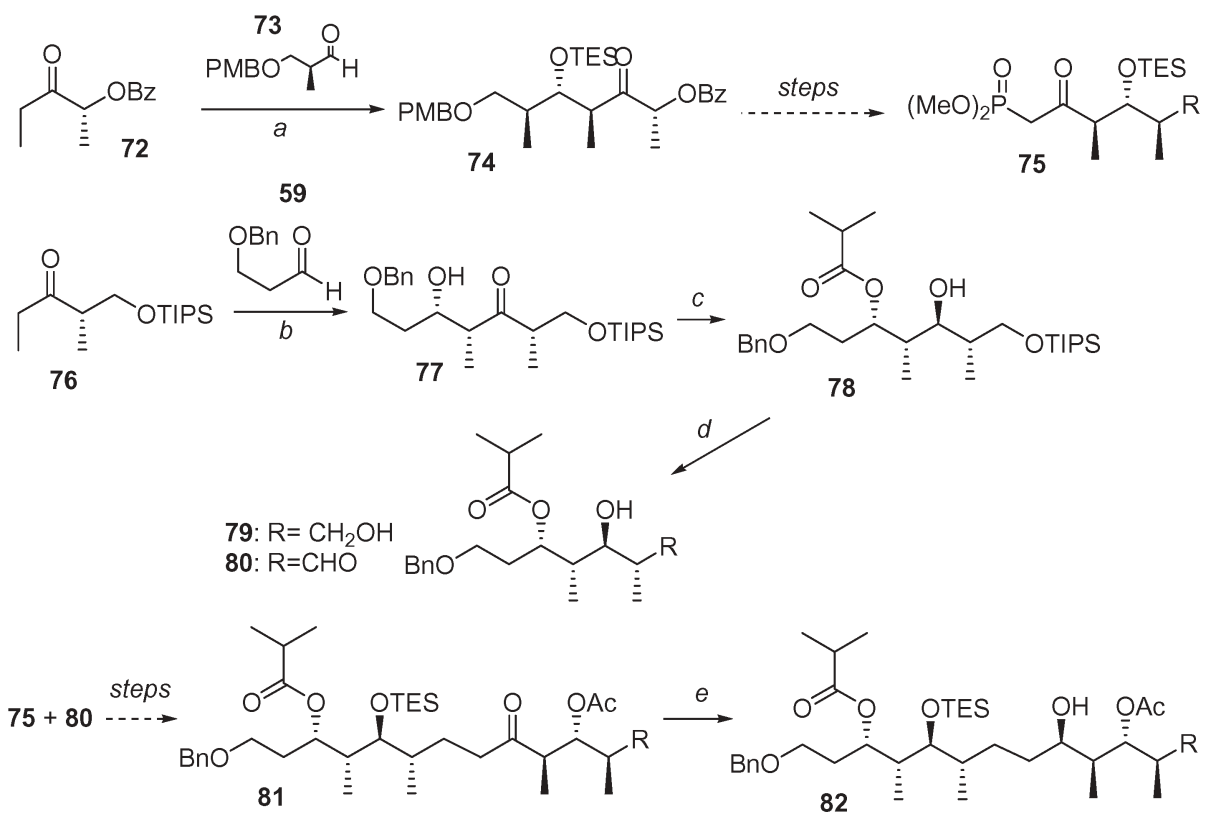

Scheme $9 a$ 1. (c-Hex $)_{2} \mathrm{BCl}, \mathrm{Me}_{2} \mathrm{NEt}, \mathrm{Et}_{2} \mathrm{O}, 0{ }^{\circ} \mathrm{C}, 1 \mathrm{~h}$, then $-78{ }^{\circ} \mathrm{C}, 73$, to $>-20{ }^{\circ} \mathrm{C}, 16 \mathrm{~h} ; 2$. TESOTf, 2,6-lutidine, $\mathrm{CH}_{2} \mathrm{Cl}_{2},-78{ }^{\circ} \mathrm{C}, 2 \mathrm{~h} ; b$ $\mathrm{Sn}(\mathrm{OTf})_{2}, \mathrm{Et}_{3} \mathrm{~N}, \mathrm{CH}_{2} \mathrm{Cl}_{2}, \mathbf{5 9},-78{ }^{\circ} \mathrm{C}, 2 \mathrm{~h} ; c$ isobutyraldehyde, $\mathrm{SmI}_{2}, \mathrm{THF}, 0{ }^{\circ} \mathrm{C}, 2.5 \mathrm{~h} ; d 1$. HF.pyridine, THF, rt, $7 \mathrm{~h} ; 2$. cat. TEMPO, PhI $(\mathrm{OAc})_{2}$, rt, $2 \mathrm{~h} ; e \mathrm{SmI}_{2}, \mathrm{CH}_{3} \mathrm{CHO}$, THF, $-5{ }^{\circ} \mathrm{C}, 2.5 \mathrm{~h}$. 

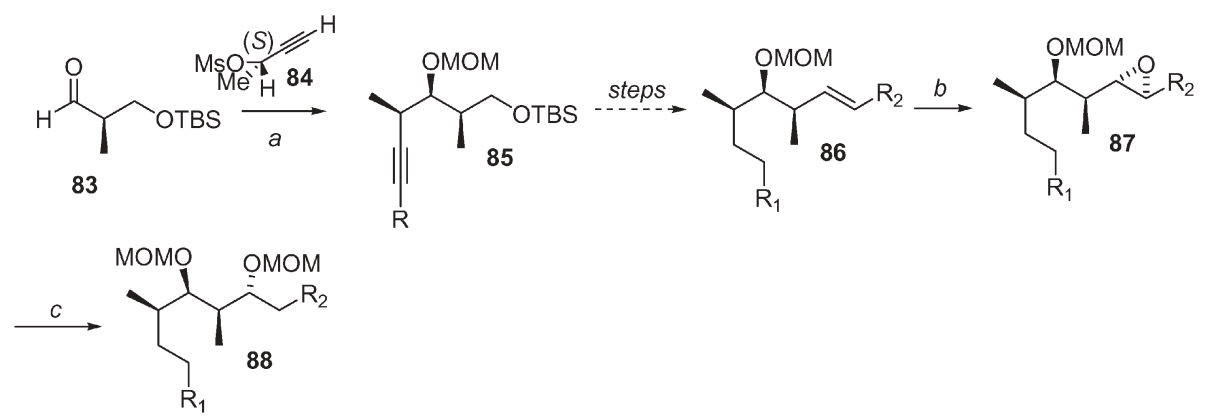

Scheme $10 a$ 1. Pd(dppf)Cl 2 , InI, THF-HMPA; 2. MOMCl, Bu ${ }_{4} \mathrm{NI}, i$-Pr ${ }_{2} \mathrm{Net} ; b(+)$-DIPT, Ti(O-i-Pr) $)_{4}, t$-BuOOH; $c$ 1. Red-Al, THF; $2 . \mathrm{MOMCl}$, $\mathrm{Bu}_{4} \mathrm{NI}, i$ - $\mathrm{Pr}_{2} \mathrm{NEt}$.
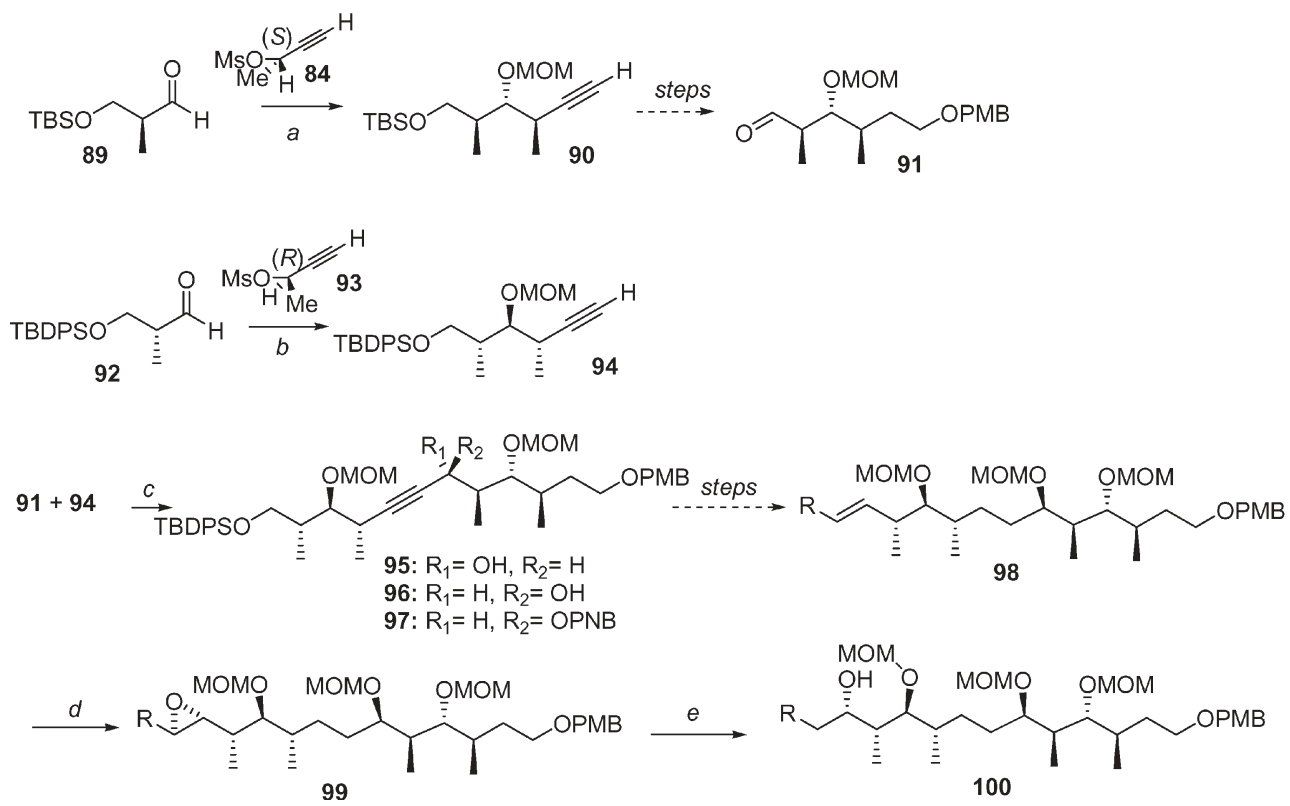

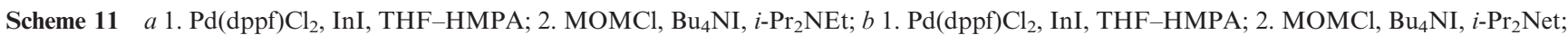
$c$ lithiation of 94, then 91; $d(-)$-DIPT, Ti(O-i-Pr $)_{4}, t-\mathrm{BuOOH} ; e \mathrm{Zn}, \mathrm{MeOH}, \triangle$.

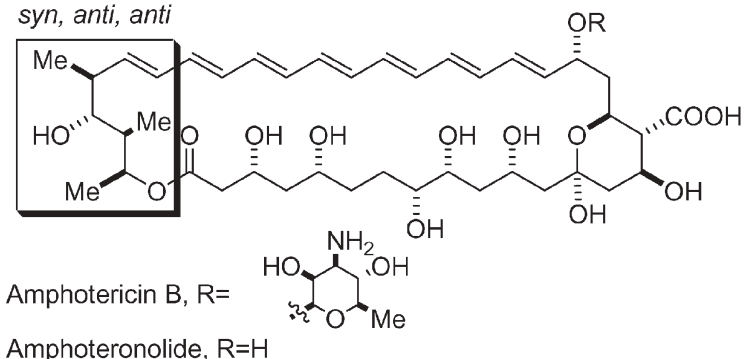

Fig. 7

K. C. Nicolaou and his group were the first ones to develop a total synthesis for amphotericin $\mathrm{B}$ and amphoteronolide $\mathrm{B} .{ }^{17}$ In their retrosynthetic analysis the syn, anti, anti stereotetrad (boxed in Fig. 7) was an independent building block. The keys for asymmetry and stereoselectivity in their synthesis of this dipropionate were the chiral starting material (+)-diethyl tartrate and Evans aldol methodology (Scheme 12). ${ }^{18}$

The enantiomerically pure epoxide $\mathbf{1 0 1}$ was readily available from (+)-diethyl tartrate. At first the epoxide 101 was converted to the Evans oxazolidinone derivative 102, the chiral auxiliary was removed and the aldehyde was masked as a pivalate. Finally, the hydroxyl groups were protected and the pivalate ester was reduced and the intermediate alcohol oxidized to produce the desired aldehyde $\mathbf{1 0 4}$.

The $\mathrm{C}(33)-\mathrm{C}(37)$ dipropionate fragment of amphotericin B has also been the target for Carreira et al. ${ }^{19}$ and us. ${ }^{20}$ Carreira's enantioselective synthesis of the stereotetrad consisted of 14 steps in $16 \%$ overall yield (Scheme 13). The key reactions from the stereochemical point of view were steps $a$ (Sharpless asymmetric dihydroxylation, $>99 \%$ ee), $d$ (>95\% de) and $g(>95 \%$ ee). Sharpless asymmetric dihydroxylation introduced the asymmetry into the molecule (step $a$ ) after which no extra external chiral information was needed.

Our own synthesis of this syn, anti, anti stereotetrad was based on the thiopyran ring strategy. ${ }^{21,22}$ Commercially available tetrahydrothiopyran-4-one was first converted to the corresponding silyl enol ether 118 (Scheme 14). The asymmetry was then introduced into the ring with the help of the tartrate derived orthoester 119. Two diastereomers were 


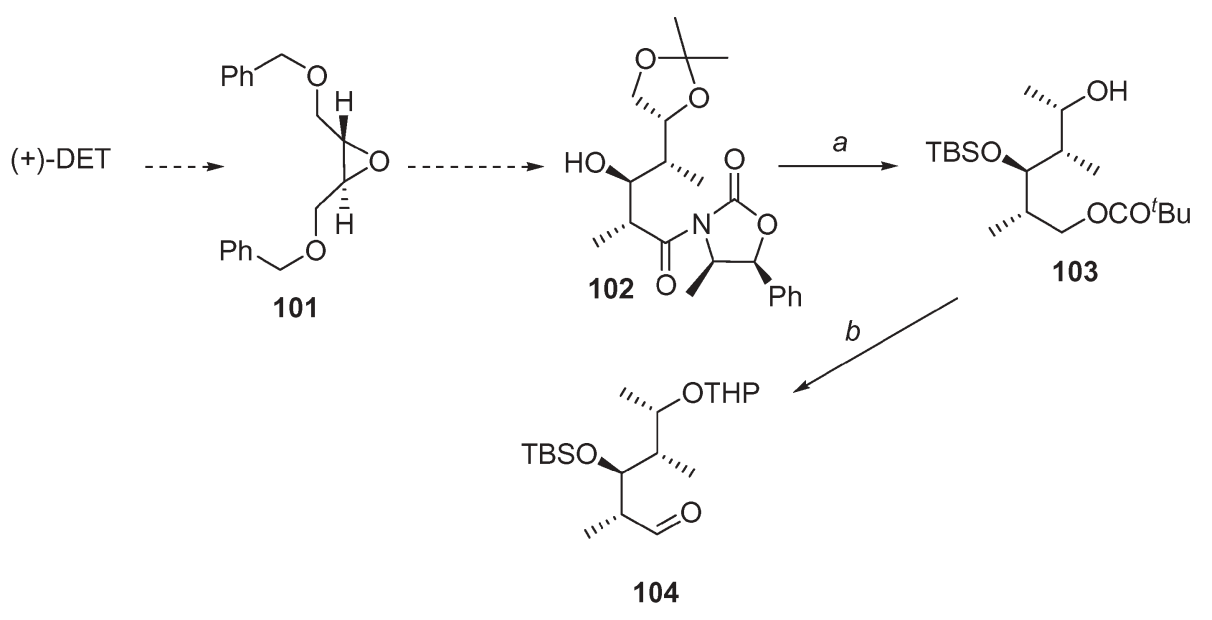

Scheme $12 a 1 . \mathrm{LiBH}_{4}, \mathrm{THF}, 0{ }^{\circ} \mathrm{C}, 0.5 \mathrm{~h}$, then $t$-BuCOCl, pyridine, $3 \mathrm{~h} ; 2 . \mathrm{Me}_{2}-t$-BuSiOTf, 2,6-lutidine, $\mathrm{CH}_{2} \mathrm{Cl}_{2}, 0{ }^{\circ} \mathrm{C}, 1 \mathrm{~h}, \mathrm{then} \mathrm{AcOH}-\mathrm{THF}-\mathrm{H}_{2} \mathrm{O}$ (3: $1: 1), 50{ }^{\circ} \mathrm{C}, 2 \mathrm{~h} ; 3$. PhSSPh, $n$-Bu 3 P, THF, $0-25^{\circ} \mathrm{C}, 3 \mathrm{~h}$, then Raney Ni, EtOH, $12 \mathrm{~h} ; b$ 1. dihydropyran, cat. $\mathrm{CSA} \mathrm{CH}_{2} \mathrm{Cl}_{2}, 0-25{ }^{\circ} \mathrm{C}, 3 \mathrm{~h} ; 2$. DIBAL-H, $\mathrm{CH}_{2} \mathrm{Cl}_{2},-78{ }^{\circ} \mathrm{C}, 0.5 \mathrm{~h}$, then $\mathrm{CrO}_{3}, \mathrm{HCl} \cdot \mathrm{pyr}, \mathrm{NaOAc}, \mathrm{CH}_{2} \mathrm{Cl}_{2}, 25{ }^{\circ} \mathrm{C}, 4 \mathrm{~h}$.

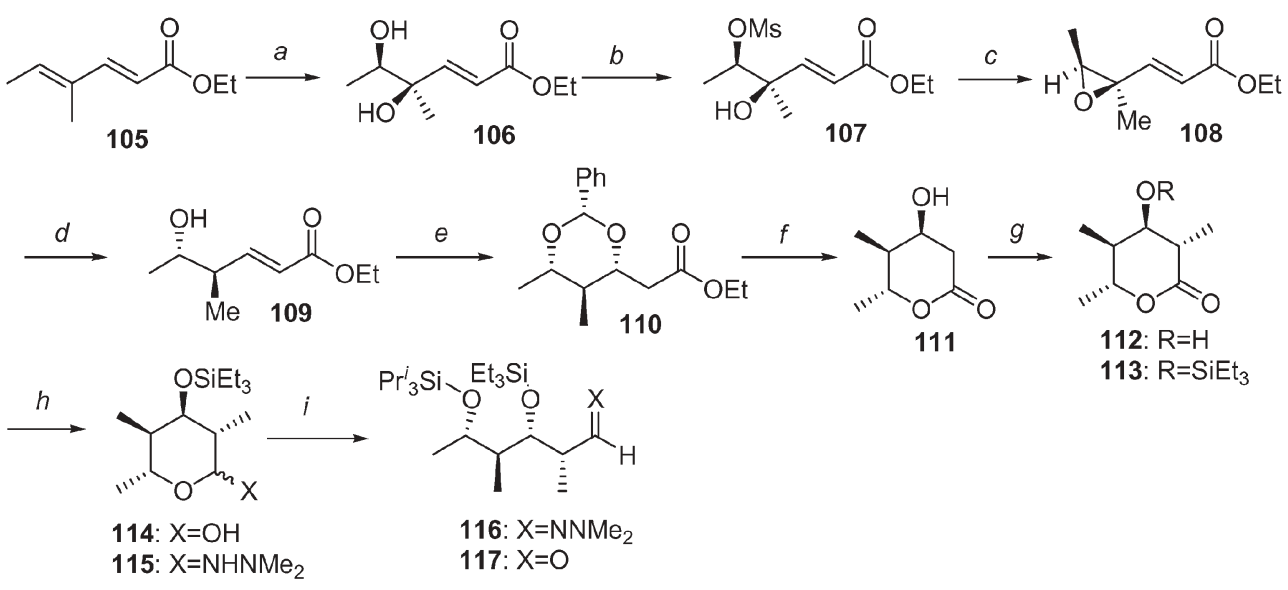

Scheme $13 a$ (DHQD) $)_{2} \mathrm{PHAL}, \mathrm{K}_{2} \mathrm{OsO}_{4} \cdot 2 \mathrm{H}_{2} \mathrm{O}, \mathrm{K}_{2} \mathrm{CO}_{3}, \mathrm{~K}_{3} \mathrm{Fe}(\mathrm{CN})_{6}, \mathrm{MeSO}_{2} \mathrm{NH}_{2}, t-\mathrm{BuOH}-\mathrm{H}_{2} \mathrm{O}, 0{ }^{\circ} \mathrm{C}, 48 \mathrm{~h} ; b \mathrm{MsCl}, \mathrm{pyridine}, \mathrm{CH}_{2} \mathrm{Cl}_{2}, 0{ }^{\circ} \mathrm{C}, 48 \mathrm{~h}$; $c \mathrm{NaH}, \mathrm{MeCN}, 0-23{ }^{\circ} \mathrm{C}, 3 \mathrm{~h} ; d\left[\mathrm{Pd}_{2}(\mathrm{dba})_{3}\right] \cdot \mathrm{CHCl}_{3}, \mathrm{Bu}_{3} \mathrm{P}, \mathrm{HCO}_{2} \mathrm{H}, \mathrm{Et}_{3} \mathrm{~N}, \mathrm{THF}, 23{ }^{\circ} \mathrm{C}, 3 \mathrm{~h} ; e \mathrm{PhCHO}, t-\mathrm{BuOK}, \mathrm{THF}, 0{ }^{\circ} \mathrm{C}, 1 \mathrm{~h} ; f 1 . \mathrm{Pd}(\mathrm{OH})_{2}, \mathrm{H}_{2}$, EtOH, $23{ }^{\circ} \mathrm{C}$; 2 . TFA-MeCN, $23{ }^{\circ} \mathrm{C}, 12 \mathrm{~h} ; g$ 1. LDA, MeI, HMPA-THF, $-78{ }^{\circ} \mathrm{C}, 16 \mathrm{~h}$; 2. 2,6-di(tert-butyl)-4-methylpyridine, $\mathrm{Et}_{3} \mathrm{SiOTf}_{\mathrm{O}} \mathrm{CH}_{2} \mathrm{Cl}_{2}$,

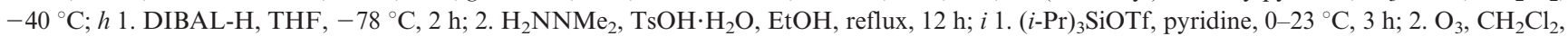
$-78{ }^{\circ} \mathrm{C}, \mathrm{Me}_{2} \mathrm{~S}$.

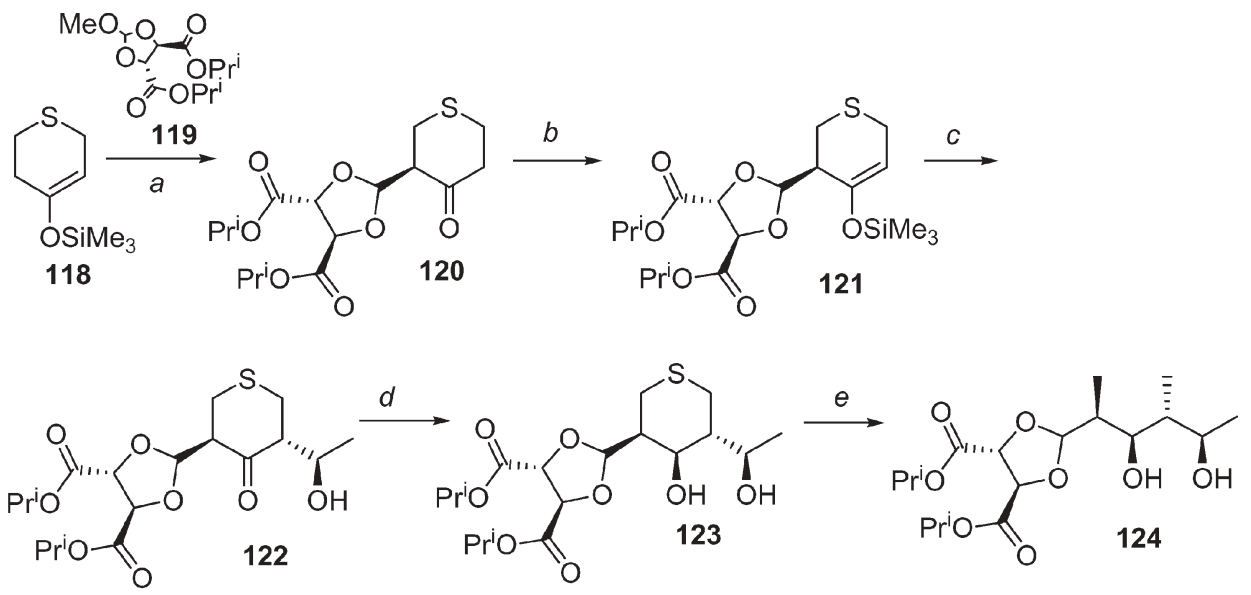

Scheme $14 a \mathrm{ZnCl}_{2}, \mathrm{CH}_{2} \mathrm{Cl}_{2}, \mathbf{5 5}, 21 \mathrm{~h}, \mathrm{rt} ; b \mathrm{LiHMDS}$, THF, TMSCl, $1 \mathrm{~h},-78{ }^{\circ} \mathrm{C}$ to $>0{ }^{\circ} \mathrm{C} ; c \mathrm{CH}_{3} \mathrm{CHO} \mathrm{TiCl}_{4}, \mathrm{CH}_{2} \mathrm{Cl}_{2}, 5 \mathrm{~min},-78{ }^{\circ} \mathrm{C} ; d$ $\mathrm{Et}_{2} \mathrm{BOMe}, \mathrm{NaBH}_{4}, \mathrm{THF}-\mathrm{MeOH}, 1 \mathrm{~h},-78{ }^{\circ} \mathrm{C}$; $e$ Raney Ni, IPA, $24 \mathrm{~h}, 70{ }^{\circ} \mathrm{C}$. 


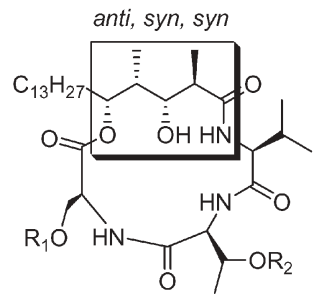

Stevastelin A: $\mathrm{R}_{1}=\mathrm{Ac}, \mathrm{R}_{2}=\mathrm{SO}_{3} \mathrm{H}$ Stevastelin $B: R_{1}=A c, R_{2}=H$

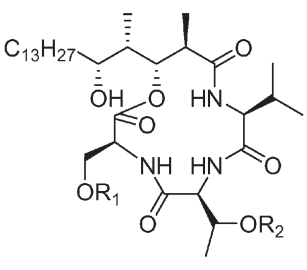

Stevastelin $\mathrm{A} 3: \mathrm{R}_{1}=\mathrm{Ac}, \mathrm{R}_{2}=\mathrm{SO}_{3} \mathrm{H}$ Stevastelin B3: $R_{1}=A c, R_{2}=H$ Stevastelin C3: $\mathrm{R}_{1}=\mathrm{H}, \mathrm{R}_{2}=\mathrm{H}$
Fig. 8

obtained in a $3: 1$ ratio and both diastereomers were successfully crystallized from the mixture. An X-ray structure of the minor diastereomer revealed the stereochemistry of $\mathbf{1 2 0}$. The next aldol reaction via the kinetic silyl enol ether 121 was highly diastereoselective and the desired aldol product $\mathbf{1 2 2}$ was obtained in reasonable yield. Finally, 1,3-syn diol reduction and removal of the sulfur with Raney Nickel produced the enantiomer of the stereotetrad of amphotericin B. The sole source of asymmetry in the whole synthesis was the chiral tartrate derived orthoester 119, which actually worked as a chiral auxiliary (masked aldehyde).

\section{4 anti, syn, syn: Stevastelins}

Stevastelins (Fig. 8) represent a family of novel depsipeptides isolated from a culture of Penicillium sp. NK374186 and they are potent immunosuppressive agents.

Two research groups have aimed their studies towards the synthesis of stevastelins. Sarabia et al. began the synthesis of

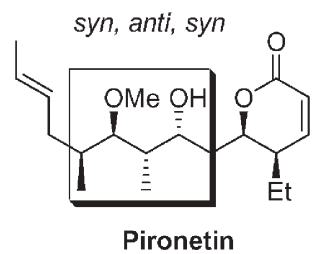

Fig. 9

the stereotetrad of stevastelins with the Evans aldol methodology to create the first two stereocenters in a syn manner (Scheme 15). ${ }^{22}$ The other two stereocenters were created via an aldol reaction of the $E$-boron enolate of $\mathbf{1 2 8}$ and the chiral aldehyde $127(\operatorname{step} c)$. Only one diastereomer, the desired anti, syn, syn product 130 was obtained.

Chakraborty et al. have reported the synthesis of the subunits of stevastelin B. $^{23}$ Their synthesis began with a Ti(IV) mediated diastereoselective non-Evans syn aldol reaction using a 2-oxazolidinethione based chiral auxiliary ${ }^{24}$ (Scheme 16). This reaction produced the desired stereotriad as the only isolable diastereomer. The fourth stereocenter was created via nucleophilic addition of the long chain Grignard reagent onto the aldehyde $\mathbf{1 3 3}$. The diastereoselectivity of this step was low: after purification the desired product 134 was obtained only in $40 \%$ yield.

\section{5 syn, anti, syn: Pironetin (PA-48153C)}

Pironetin (PA-48153C) (Fig. 9) was isolated in 1993 independently by two Japanese research groups from the fermentation broths of Streptomyces sp. NK10958 and Streptomyces prunicolor PA-48153.

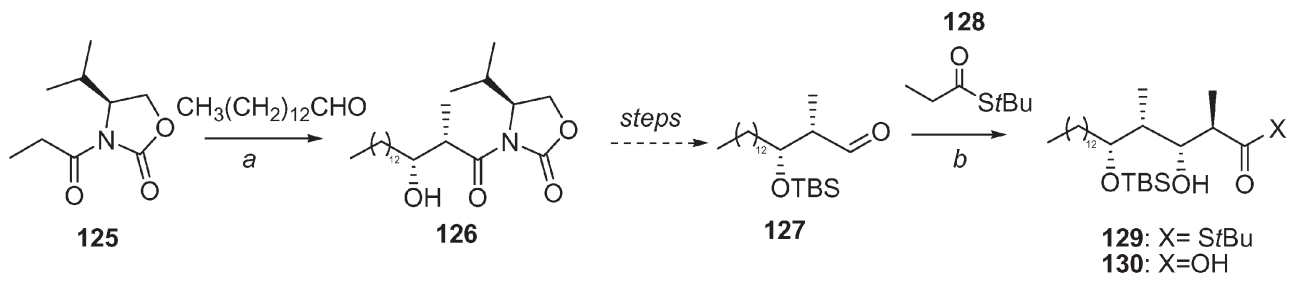

Scheme $15 a n$ - $\mathrm{Bu}_{2} \mathrm{BOTf}, \mathrm{Et}_{3} \mathrm{~N}, \mathrm{CH}_{2} \mathrm{Cl}_{2}, 0{ }^{\circ} \mathrm{C}, 0.5 \mathrm{~h}$, then $-78{ }^{\circ} \mathrm{C}$, tetradecanal, $12 \mathrm{~h} ; b \mathbf{1 2 8},(\mathrm{Chx})_{2} \mathrm{BCl}, \mathrm{Et}_{3} \mathrm{~N}, \mathrm{CH}_{2} \mathrm{Cl}_{2}, 0{ }^{\circ} \mathrm{C}, 2 \mathrm{~h}$, then $-78{ }^{\circ} \mathrm{C}$, 127, $12 \mathrm{~h}$, oxidative work-up.

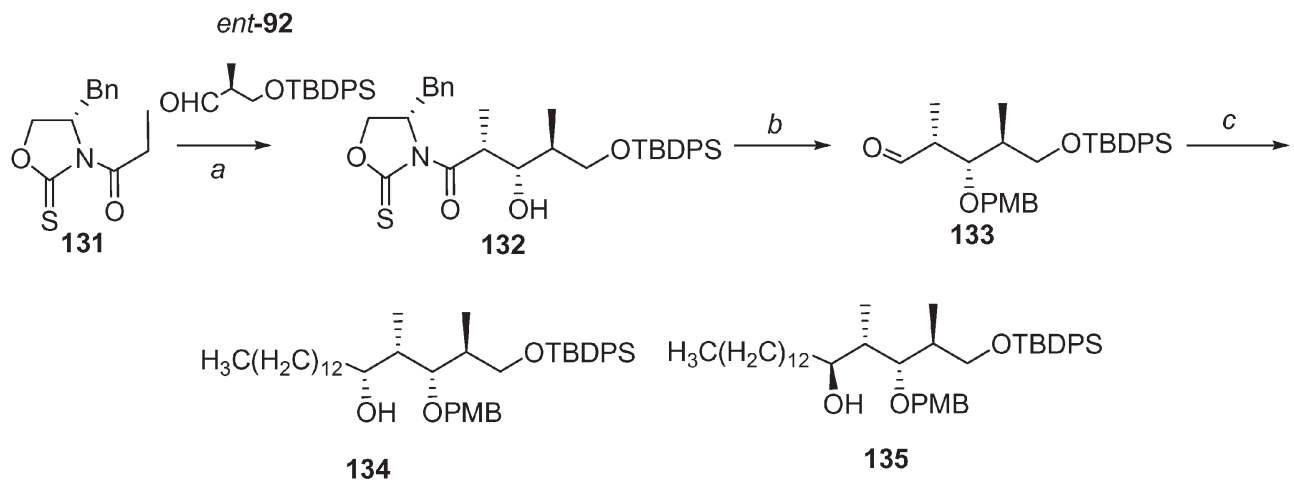

Scheme $16 a \mathrm{TiCl}_{4}$, DIPEA, $\mathrm{CH}_{2} \mathrm{Cl}_{2},-78{ }^{\circ} \mathrm{C} ; b 1 . \mathrm{NaBH}_{4}, \mathrm{EtOH}, 0{ }^{\circ} \mathrm{C} ; 2 . \mathrm{MeOPhCH}(\mathrm{OMe})_{2}, \mathrm{CSA}\left(\mathrm{cat}\right.$.), $\mathrm{CH}_{2} \mathrm{Cl}_{2} ; 3 . \mathrm{DIBAL}^{-\mathrm{H}}, \mathrm{CH}_{2} \mathrm{Cl}_{2},-78{ }^{\circ} \mathrm{C}$ to $>0{ }^{\circ} \mathrm{C}$; 4 . Swern oxidation; $c \mathrm{CH}_{3}\left(\mathrm{CH}_{2}\right)_{12} \mathrm{MgBr}$, THF, $0{ }^{\circ} \mathrm{C}$ to $>$ rt. 

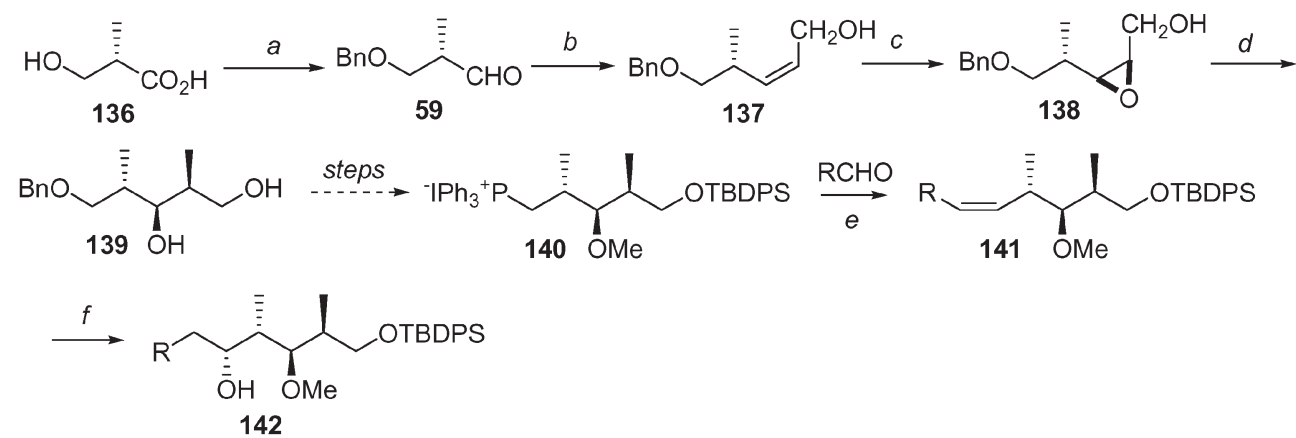

Scheme 17 a 1. $\mathrm{PhCH}_{2} \mathrm{OC}(=\mathrm{NH}) \mathrm{CCl}_{3}, \mathrm{CF}_{3} \mathrm{SO}_{3} \mathrm{H} ; 2$. $\mathrm{LiAlH}_{4} ; 3$. Swern oxidation; $b$ 1. $\left(\mathrm{CF}_{3} \mathrm{CH}_{2} \mathrm{O}\right)_{2} \mathrm{P}(=\mathrm{O}) \mathrm{CH}_{2} \mathrm{CO}_{2} \mathrm{Me}, \mathrm{KN}(\mathrm{TMS})_{2}, 18-\mathrm{Crown}-6$; 2. DIBAL-H; $c$ MCPBA; $d \mathrm{Me}_{2} \mathrm{CuLi} ;$ e $n$-BuLi; $f \mathrm{~B}_{2} \mathrm{H}_{6}, \mathrm{H}_{2} \mathrm{O}_{2}$.

The structure of pironetin, the unsaturated $\delta$-lactone ring joined to the syn, anti, syn stereotetrad, has attracted many research groups since its isolation, and several total syntheses have been published so far.

The first total synthesis of pironetin by Yasui et al. was published two years after its isolation (Scheme 17). ${ }^{25}$ The synthesis of the stereotetrad was very straightforward and the keys in the synthesis were the chiral precursor 136, asymmetric epoxidation $(\operatorname{step} c)$ and hydroboration $(\operatorname{step} f)$.

Gurjar et al based their synthesis of the dipropionate of pironetin on the chiral precursor $\mathbf{1 4 3}$ and Sharpless asymmetric epoxidation (Scheme 18). ${ }^{26}$

Chida's synthesis of the stereotetrad of pironetin was started from L-quebrachitol 149 (Scheme 19). The intermediate 150 was prepared in five steps. ${ }^{27}$ Two stereocenters were inverted via base treatment of $\mathbf{1 5 0}$ to produce the epoxide $\mathbf{1 5 1}$ followed by trans-diaxial opening of the epoxide with the methyl nucleophile and protection. Intermediate $\mathbf{1 5 2}$ already had the desired stereochemistry. Finally, 152 was deketalized and opened to produce the acyclic syn, anti, syn stereotetrad 154 of pironetin.

Watanabe et al. used the chiral precursor $\mathbf{1 5 5}$ as the starting material in their synthesis of the stereotetrad fragment of pironetin (Scheme 20). ${ }^{28}$ All stereochemical information emanated from the chiral cyclohexanone derivative $\mathbf{1 5 5}$ and the chiral R chain, which was coupled to $\mathbf{1 6 1}$ in high yield and diastereoselectivity (step $g$ ).

Keck et al. initiated their synthesis with chelation controlled $\left(\mathrm{TiCl}_{4}\right)$ addition of $(Z)$-crotyltri- $n$-butylstannane $\mathbf{1 6 5}$ to the $\beta$-benzyloxy aldehyde ent-15 to give the anti, syn homoallylic alcohol 166 (Scheme 21). ${ }^{29}$ The fourth stereocenter of the stereotetrad was created via an aldol reaction between the stereotriad aldehyde $\mathbf{1 6 7}$ and the chiral TMS enol ether $\mathbf{1 6 8}$ using $\mathrm{BF}_{3} \cdot \mathrm{OEt}$ as the Lewis acid. The desired diastereomer 169

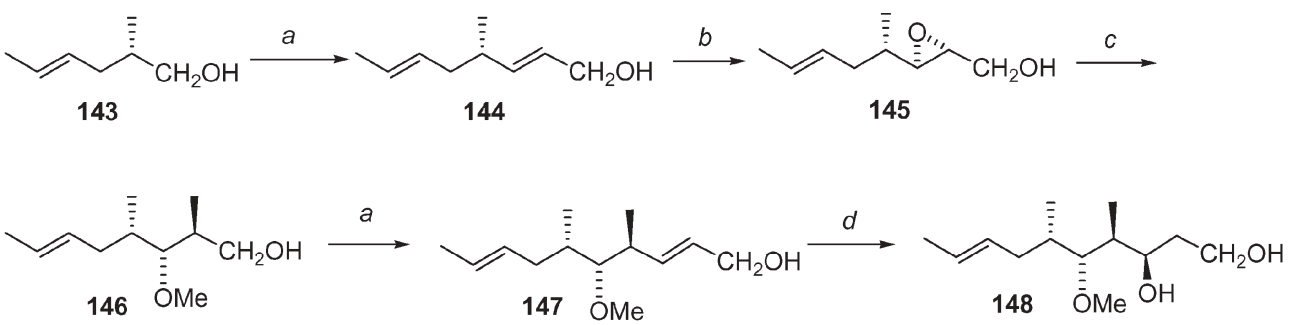

Scheme $18 a$ 1. IBX, DMSO, rt, $30 \mathrm{~min} ; 2 . \mathrm{Ph}_{3}=\mathrm{CHCO}_{2} \mathrm{Et}$, benzene, rt, $3 \mathrm{~h} ; 3$. DIBAL-H, $\mathrm{CH}_{2} \mathrm{Cl}_{2},-20{ }^{\circ} \mathrm{C}, 30 \mathrm{~min} ; b \mathrm{TBHP}, \mathrm{Ti}(\mathrm{O} i \mathrm{Pr})_{4}$, (-)-DIPT, $\mathrm{CH}_{2} \mathrm{Cl}_{2},-2{ }^{\circ} \mathrm{C}, 20 \mathrm{~h} ; c 1 . \mathrm{Me}_{2} \mathrm{CuLi}, \mathrm{Et}_{2} \mathrm{O},-78{ }^{\circ} \mathrm{C}, 8 \mathrm{~h} ; 2$. TBSCl, imidazole, $\mathrm{CH}_{2} \mathrm{Cl}_{2}, \mathrm{rt}, 3 \mathrm{~h} ; 3$. KH, MeI, Et $2 \mathrm{O}, \mathrm{rt}, 30 \mathrm{~min} ; 4 . \mathrm{Bu}{ }_{4} \mathrm{NF}$, THF, rt, $2 \mathrm{~h} ; d$ 1. TBHP, Ti(OiPr $)_{4},(+)$-DIPT, $\mathrm{CH}_{2} \mathrm{Cl}_{2},-20{ }^{\circ} \mathrm{C}, 18 \mathrm{~h}$; 2. Red-Al, THF, $0{ }^{\circ} \mathrm{C}, 4 \mathrm{~h}$.
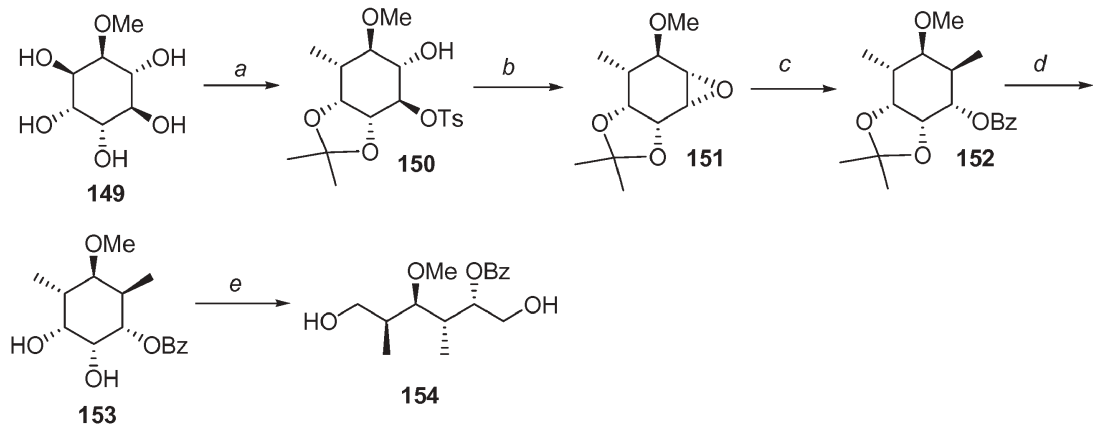

Scheme $19 a$ 1. ref. 36; 2. $\mathrm{Bu}_{2} \mathrm{SnO}, \mathrm{MeOH}$, reflux, then TsCl, DMAP; 3. 1,4-dioxane, rt; $b \mathrm{MeONa}, \mathrm{MeOH}$, reflux; $c 1 . \mathrm{Me}_{3} \mathrm{Al}, \mathrm{CH}_{2} \mathrm{Cl}_{2}:$ hexanes, $\mathrm{rt}$; 2. $\mathrm{BzCl}$, pyridine, DMAP, $\mathrm{rt} ; d$ 10-camphorsulfonic acid, $\mathrm{MeOH}, \mathrm{rt}$; $e \mathrm{NaIO}_{4}$, acetone- $\mathrm{H}_{2} \mathrm{O}, 0{ }^{\circ} \mathrm{C}$, then $\mathrm{NaBH}_{4}, \mathrm{MeOH}^{\circ}{ }^{\circ} \mathrm{C}$. 


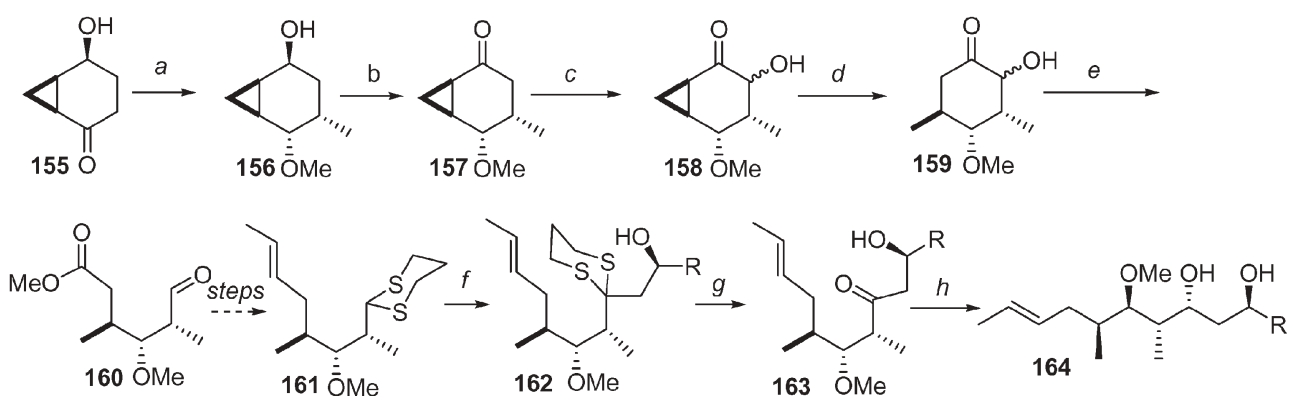

Scheme $20 a$ 1. DHP, PPTS, $\mathrm{CH}_{2} \mathrm{Cl}_{2}, \mathrm{rt} ; 2$. LDA, HMPA, THF, $-78^{\circ} \mathrm{C}$, then MeI; 3. L-Selectride, THF, $-78^{\circ} \mathrm{C} ; 4$. NaH, MeI, TBAI, THF, 60 ${ }^{\circ} \mathrm{C}$; 5. aq. $\mathrm{HCl}, \mathrm{MeOH}, 0{ }^{\circ} \mathrm{C} ; b$ Dess-Martin oxidation; $c$. TBSOTf, $\mathrm{Et}_{3} \mathrm{~N}, \mathrm{CH}_{2} \mathrm{Cl}_{2}, 0{ }^{\circ} \mathrm{C}$; 2. cat. OsO $\mathrm{O}_{4}, \mathrm{NMO}, \mathrm{THF}, \mathrm{H}_{2} \mathrm{O}, \mathrm{rt} ; d$ LHMDS, THF, $-78{ }^{\circ} \mathrm{C}$, then $\mathrm{Li}$, liq. $\mathrm{NH}_{3}$, then $\mathrm{NH}_{4} \mathrm{Cl} ; e \mathrm{~Pb}(\mathrm{OAc})_{4}$, benzene, $\mathrm{MeOH}$, rt; $f n$-BuLi, HMPA, THF, $0{ }^{\circ} \mathrm{C}$, then $\mathrm{RX} ; g \mathrm{Hg}\left(\mathrm{CIO}_{4}\right)_{2}, \mathrm{CaCO}_{3}, \mathrm{THF}, \mathrm{H}_{2} \mathrm{O}$, $\mathrm{rt} ; h \operatorname{LiAlH}(\mathrm{O} t \mathrm{Bu})_{3}$, LiI, ether, $-78{ }^{\circ} \mathrm{C}$ to $>0{ }^{\circ} \mathrm{C}$.

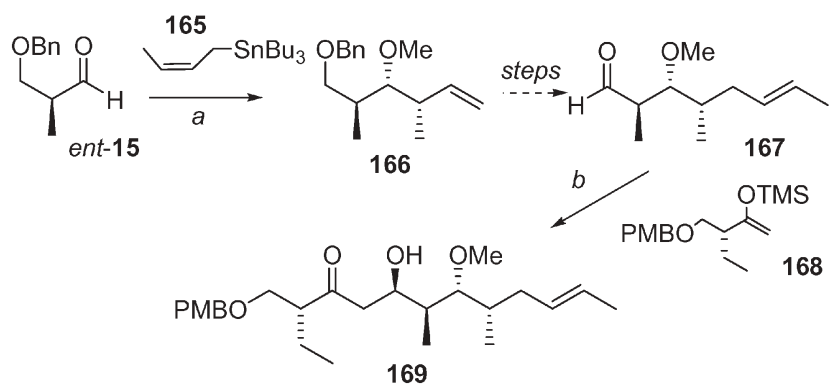

Scheme $21 a 1.165, \mathrm{TiCl}_{4}$ 2. KH, MeI; $b$ 168, $\mathrm{BF}_{3} \cdot$ OEt.

was the only product in this reaction; none of the other diastereomers was detected.

The most recently published total synthesis of pironetin by Dias et al. was based on the Evans aldol chemistry
(Scheme 22). ${ }^{30}$ This route was very short and efficient but it needed external chiral information twice for building up the desired stereochemistry (steps $a$ and $c$ ).

\section{6 syn, syn, syn: Erythromycin A/B and Erythronolide A/B}

Erythromycins and erythronolides (Fig. 10), and their derivatives belong to macrolide antibiotics. Erythromycin A was isolated in the early 1950's from a strain of Streptomyces erythraeus, and its complete structure was revealed in 1965 by $\mathrm{X}$-ray analysis. The antibiotic activity of erythromycins is related to their ability to inhibit ribosomal-dependent protein biosynthesis. $^{31}$

For over four decades the challenging structures of erythromycins and erythronolides have attracted many research groups, ${ }^{32}$ but only a few total syntheses have been reported so far. In this chapter, the first two and

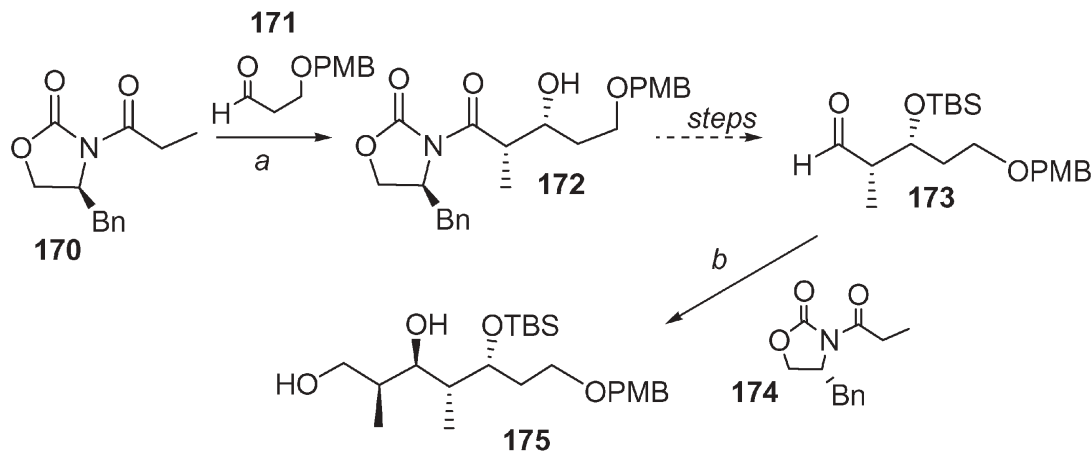

Scheme 22 a $n$ - $\mathrm{Bu}_{2} \mathrm{BOTf}, \mathrm{CH}_{2} \mathrm{Cl}_{2}, \mathrm{Et}_{3} \mathrm{~N},-5{ }^{\circ} \mathrm{C}$, then $-78{ }^{\circ} \mathrm{C}, \mathbf{1 7 1} ; b 1 . \mathbf{1 7 4}, n-\mathrm{Bu}_{2} \mathrm{BOTf}, \mathrm{CH}_{2} \mathrm{Cl}_{2}, \mathrm{Et}_{3} \mathrm{~N},-5{ }^{\circ} \mathrm{C}$, then $-78{ }^{\circ} \mathrm{C}, 173 ; 2 . \mathrm{LiBH}$, $\mathrm{THF}-\mathrm{MeOH}, 0{ }^{\circ} \mathrm{C}$.

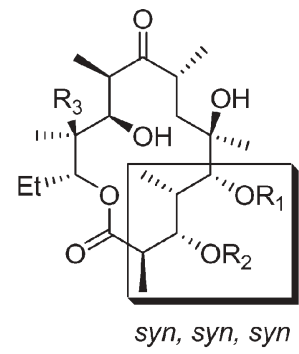

syn, syn, syn

\section{Erythromycin A}

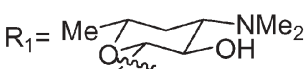

Erythromycin B

$\mathrm{R}_{2}={ }_{\mathrm{seO}}^{-\mathrm{s}} \mathrm{Me}_{\mathrm{HO}}^{\mathrm{O}} \mathrm{Me}$
$\mathrm{R}_{3}=\mathrm{OH}$
$\mathrm{R}_{1}=\mathrm{Me} \widetilde{\mathrm{T}_{\text {s. }}} \mathrm{LOH}_{\mathrm{OH}}$

$\mathrm{R}_{2}={ }_{\mathrm{MeO}}^{-\mathrm{s}} \mathrm{He}_{\mathrm{HO}}^{\mathrm{O}} \mathrm{Me}$

$\mathrm{R}_{3}=\mathrm{H}$

\section{Erythronolide A}

$R_{1}=H$
$R_{2}=H$

$\mathrm{R}_{3}=\mathrm{OH}$

\section{Erythronolide $B$}

$\mathrm{R}_{1}=\mathrm{H}$

$\mathrm{R}_{2}=\mathrm{H}$

$\mathrm{R}_{3}=\mathrm{H}$ 

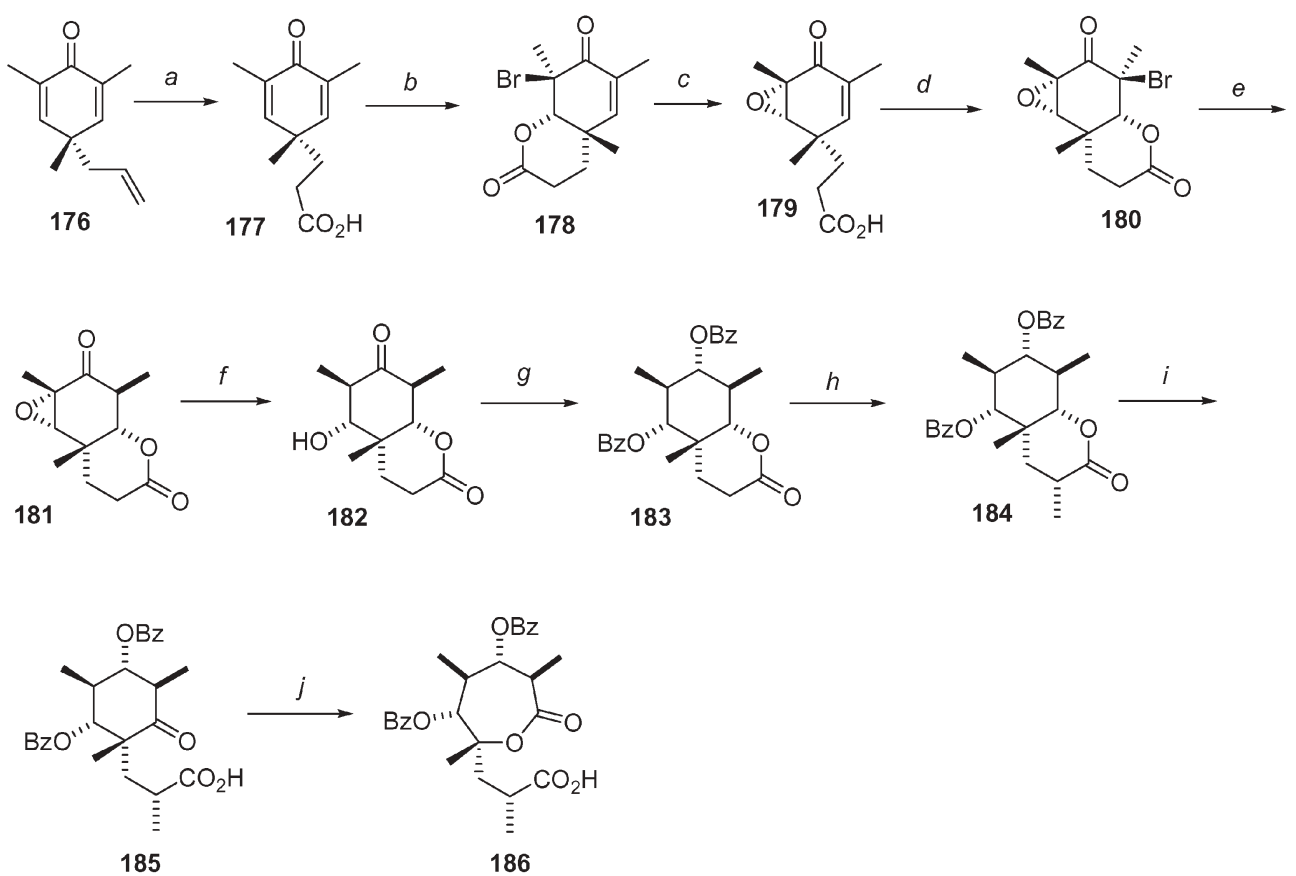

Scheme $23 a 1 . \mathrm{B}_{2} \mathrm{H}_{6}$, THF, $0-10{ }^{\circ} \mathrm{C} ; 2$. Jones chromic acid, $0--10{ }^{\circ} \mathrm{C} ; b \mathrm{Br}_{2}, \mathrm{KBr}, \mathrm{H}_{2} \mathrm{O} ; c$ aq. $\mathrm{KOH}, \mathrm{THF} ; d$ Br $2, \mathrm{KBr}, \mathrm{H}_{2} \mathrm{O} ; e \mathrm{Bu} \mathrm{SnH}_{3}, \mathrm{AIBN}$, $\mathrm{PhH} ; f \mathrm{Al} / \mathrm{Hg}$, THF, $\mathrm{H}_{2} 0,0$ to $-10{ }^{\circ} \mathrm{C} ; g 1 . \mathrm{H}_{2}$, Raney Ni, DME, $-20{ }^{\circ} \mathrm{C} ; 2$. BzCl, pyridine; $h \mathrm{LDA}, \mathrm{THF},-78{ }^{\circ} \mathrm{C}$, then MeI, $\mathrm{HMPA},-78{ }^{\circ} \mathrm{C}$ to $>-45{ }^{\circ} \mathrm{C} ; i$. $\mathrm{LiOH}, \mathrm{H}_{2} \mathrm{O} ; 2 . \mathrm{CrO}_{3}, \mathrm{H}_{2} \mathrm{SO}_{4}$, acetone, $-10{ }^{\circ} \mathrm{C} ; j \mathrm{MeCO}_{3} \mathrm{H}$, EtOAc, $55^{\circ} \mathrm{C}$.

the two most recent syntheses of the stereotetrad of erythromycins/erythronolides (boxed in Fig. 10) are discussed in detail.

E. J. Corey et al. published in 1978 the first total synthesis of ( \pm )-erythronolide B (Scheme 23). ${ }^{33}$ The creation of the syn, syn, syn stereotetrad began from the achiral dienone $\mathbf{1 7 6}$ by hydroboration followed by oxidation, to produce the dienone acid 177. Treatment with bromine-potassium bromide solution yielded the bromo lactone $\mathbf{1 7 8}$, which was then converted under basic reaction conditions to the epoxy acid 179. The epoxy acid 179 was then converted to the bromo epoxy lactone 180, from which the bromine was cleaved via radical reaction to produce the epoxy lactone 181. Epoxide 181 was reductively opened and the ketone $\mathbf{1 8 2}$ was then stereoselectively reduced. The hydroxyl groups were then protected to produce the dibenzoate 183, which already possessed the all-syn stereochemistry. Dibenzoate $\mathbf{1 8 3}$ was finally transformed to lactone 186, which was one of the key intermediates in the first total synthesis of erythronolide A.

Woodward et al. completed the first (and also so far the only one) total synthesis of Erythromycin $\mathrm{A}$ in $1981 .{ }^{34}$ Thiopyranone ring strategy was the key for the successful total synthesis as well as for the synthesis of the syn, syn, syn stereotetrad (Scheme 24).
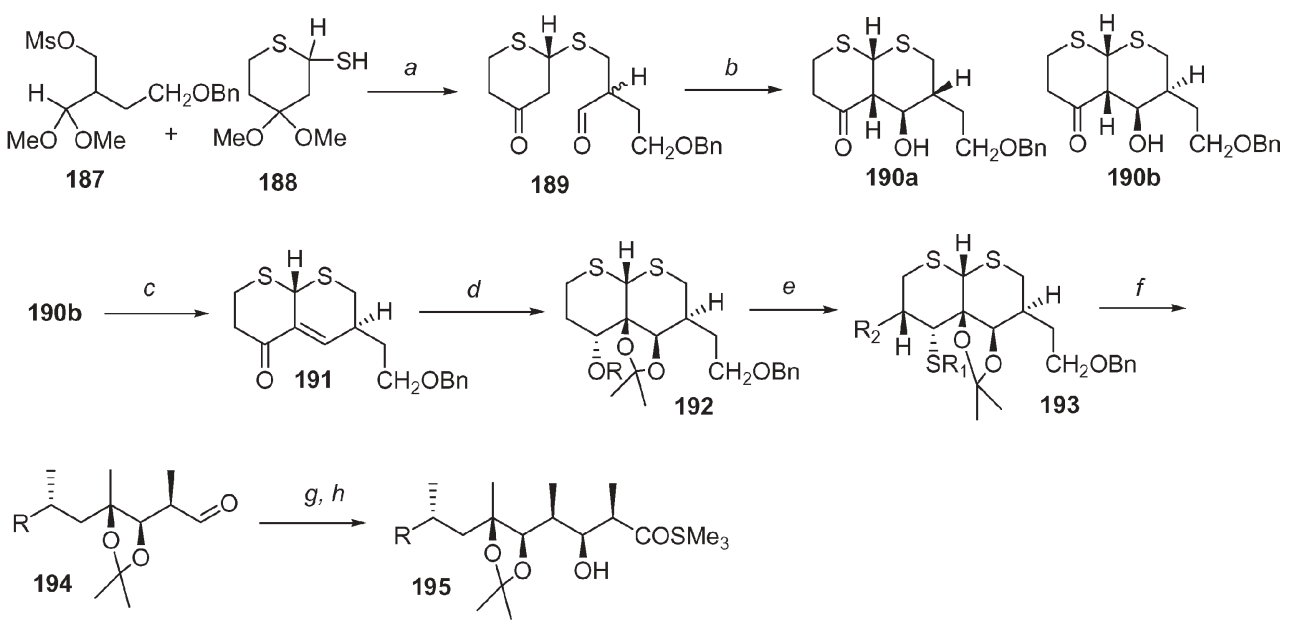

Scheme $24 a$ 1. NaH, THF, DMSO, rt; 2. AcOH, $\mathrm{H}_{2} \mathrm{O}$, rt; $b$ D-Pro, $\mathrm{PhH}-\mathrm{MeOH}, \mathrm{rt} ; c 1 . \mathrm{MsCl}, \mathrm{py} ; 2 . \mathrm{Al}_{2} \mathrm{O}_{3}, \mathrm{EtOAc} ; d 1 . \mathrm{NaBH}_{4}, \mathrm{MeOH}^{\circ}{ }^{\circ} \mathrm{C} ; 2$. $\mathrm{MeOCH}_{2} \mathrm{I}, \mathrm{KH}$, THF; 3. $\mathrm{OsO}_{4}, \mathrm{Et}_{2} \mathrm{O}$, then $\mathrm{NaHSO}_{3}$, py; 4. $\mathrm{Me}_{2} \mathrm{C}(\mathrm{OMe})_{2}, \mathrm{TsOH}, \mathrm{CH}_{2} \mathrm{Cl}_{2} ; e$ six steps; $f$ 1. Raney Ni (W2), EtOH, DMF, rfx; 2. $o-\mathrm{NO}_{2} \mathrm{PhSeCN}, n \mathrm{Bu}_{3} \mathrm{P}$, THF, $30 \% \mathrm{H}_{2} \mathrm{O}_{2}$, THF, rt; $3 . \mathrm{O}_{3}, \mathrm{MeOH}, \mathrm{CH}_{2} \mathrm{Cl}_{2},-78{ }^{\circ} \mathrm{C}$, then $\mathrm{Me}_{2} \mathrm{~S}, \mathrm{NaHCO}_{3} ; g$. EtCOSCMe 3 , LDA, THF, $-110{ }^{\circ} \mathrm{C}$; 2. $t$-BuLi, THF, $-110{ }^{\circ} \mathrm{C}$, then $\mathrm{AcOH},-110{ }^{\circ} \mathrm{C} ; h 1 . t$ - BuLi, $\left(\mathrm{CH}_{2} \mathrm{NMe}_{2}\right)_{2}, \mathrm{THF},-110{ }^{\circ} \mathrm{C} ; 2 . \mathrm{AcOH},-110{ }^{\circ} \mathrm{C}$. 
The synthesis of the syn, syn, syn stereotetrad began from the racemic starting materials 187 and 188. The racemic intermediate 189 was allowed to undergo an intramolecular aldol reaction catalyzed by D-proline, and a $1: 1$ mixture of enantiomerically enriched diastereomers 190a and 190b were obtained ( $36 \%$ ee for both diastereomers). The synthesis was continued with 190b and the enantiomerically enriched enone 191 was obtained after dehydration. The desired enantiomer (+)-191 crystallized out from the enantiomeric mixture and the synthesis was continued with optically pure material. Then, $\mathrm{NaBH}_{4}$ reduction and $\mathrm{OsO}_{4}$ oxidation gave stereospecifically the key intermediate 192 in good yield and stereoselectivity.

The final stages in building up the all-syn-stereotetrad were very straightforward. After desulfurisation, deprotection and oxidation ( $\operatorname{step} f$ ), aldehyde 194 was allowed to react with the enolate of tert-butyl thiopropionate. The product, the undesired Cram aldol adduct (wrong stereochemistry at C2) was finally inverted via kinetic protonation to the desired syn, syn, syn product 195.

Evans and Kim published the total synthesis of 6-deoxyerythronolide B (biosynthetic precursor of erythromycins) in 1997. ${ }^{35}$ The Evans all-syn-stereotetrad synthesis was very short and highly stereoselective (Scheme 25). The $\beta$-ketoimide 196 was allowed to react with methacrolein $\left(\mathrm{TiCl}_{4}\right.$ as the Lewis acid) followed by a 1,3-syn reduction and ketal protection of the diol to produce the stereotetrad 198 in excellent yield and stereoselectivity.

The most recent total synthesis of erythromycins was published in 2003 by Martin et al. (Scheme 26). ${ }^{36}$ The synthesis of the syn, syn, syn stereotetrad fragment started with Evans aldol chemistry to give the aldol adduct $\mathbf{2 0 1}$ as the only isomer (step $a$ ). After several reaction steps, which concentrated on the synthesis of the left half of erythromycin B, two missing stereocenters of the syn, syn, syn stereotetrad were created via asymmetric crotylation ( $\operatorname{step} e$ ).

\section{Conclusions}

The stereotetrad is a common substructure in polypropionate natural products. Four stereogenic centers next to each other result in eight possible diastereomeric combinations of this structure. Thus, an asymmetric synthesis of each of these combinations (anti, anti, anti; anti, anti, syn; anti, syn, anti; syn, anti, anti; syn, syn, anti; syn, anti, syn; anti, syn, syn and syn, syn, syn) demands accurate planning and careful realization in the laboratory. When the synthesis of a stereotetrad is a part of a total synthesis of a more complex molecule the situation becomes even more complicated. If the stereotetrad fragment can be cleaved retrosynthetically into an independent sub-goal, its synthesis is often more straightforward than in the case where the stereochemistry of the stereotetrad is created by a linear approach. In the latter situation, the stereochemistry and structure of the remaining molecule has to be considered and it usually limits the possible strategies to a minimum.

Some interesting points can be noted. It was a big surprise to discover, that the linear structure of the syn, syn, anti stereotetrad (as a fragment of a natural product) was not found with a database search. Even if the conclusion, that the $s y n$, syn, anti stereotetrad does not exist in natural products, cannot be drawn, it is evident that this structure is very rare in nature. It was also interesting to notice that the syntheses of all different stereotetrads were mostly based on $i$ ) Evans

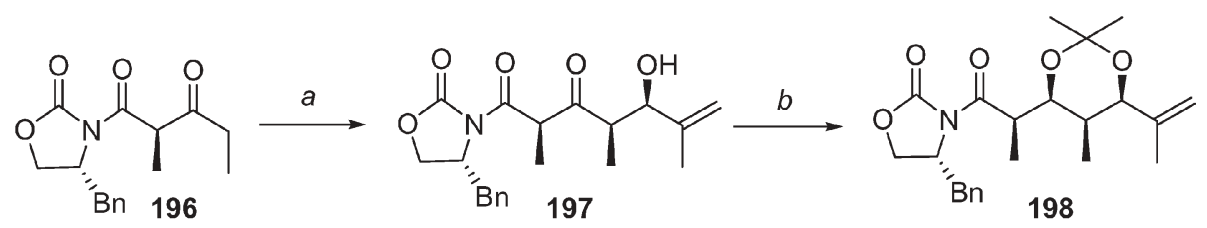

Scheme $25 a \mathrm{TiCl}_{4}, i-\mathrm{Pr}_{2} \mathrm{NEt}$, methacrolein, $0{ }^{\circ} \mathrm{C}, \mathrm{CH}_{2} \mathrm{Cl}_{2} ; b 1 . \mathrm{Zn}\left(\mathrm{BH}_{4}\right)_{2},-78{ }^{\circ} \mathrm{C}_{,} \mathrm{CH}_{2} \mathrm{Cl}_{2} ; 2 . \mathrm{Me}_{2} \mathrm{C}(\mathrm{OMe})_{2}, \mathrm{CSA}, 25^{\circ} \mathrm{C}, \mathrm{CH}_{2} \mathrm{Cl}{ }_{2}$.
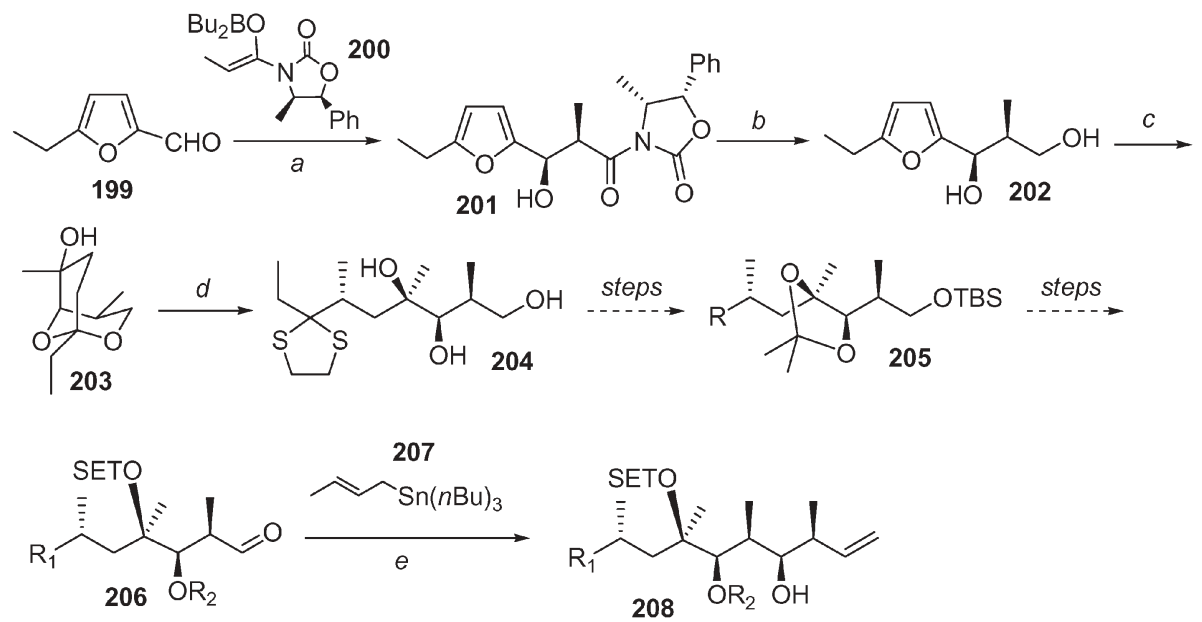

Scheme 26 a 200, $\mathrm{CH}_{2} \mathrm{Cl}_{2}, \mathbf{1 9 9} ; b \mathrm{LiBH}_{4}$, THF; $c$ 1. $\mathrm{Br}_{2}, \mathrm{MeCN}, \mathrm{H}_{2} \mathrm{O} ; 2 . \mathrm{Me}_{2} \mathrm{CuLi} ; 3 . \mathrm{MeLi}, \mathrm{CeCl}_{3} ; d \mathrm{TMSSCH}_{2} \mathrm{CH}_{2} \mathrm{STMS}_{\mathrm{T}}$, TiCl 4 ; e 206, 207, $\mathrm{BF}_{3}$. OEt, $\mathrm{CH}_{2} \mathrm{Cl}_{2}$. 
asymmetric aldol methodology, ii) Sharpless asymmetric epoxidation and dihydroxylation, iii) asymmetric crotylations and $i v$ ) diastereoselective aldol reaction between an aldehyde and an $E$-enolate of a ketone.

\section{References}

1 A. J. Birch, Science, 1967, 156, 202.

2 J. Rohr, Angew. Chem., Int. Ed., 2000, 39, 2847.

3 A. Koskinen, Asymmetric Synthesis of Natural Products, John Wiley \& Sons Ltd, Chichester, 1993.

4 V. Parpura, T. A. Basrsky, F. Liu, K. Jeftinija, S. Jeftinija and P. G. Haydon, Nature, 1994, 369, 744.

5 D. A. Evans, R. L. Dow, T. L. Shih, J. M. Takacs and R. Zahler, J. Am. Chem. Soc., 1990, 112, 5290.

6 S. Hanessian, N. G. Cooke, B. DeHoff and Y. Sakito, J. Am. Chem. Soc., 1990, 112, 5276.

7 M. Lautens, J. T. Colucci, S. Hiebert, N. D. Smith and G. Bouchain, Org. Lett., 2002, 4, 1879.

8 J. E. Sheppeck, C.-M. Gauss and A. R. Chamberlin, Bioorg. Med. Chem., 1997, 5, 1739.

9 A. M. P. Koskinen and P. M. Pihko, Chemistry and Biology of Calyculin C, in Current Trends in Organic Synthesis, ed. C. Scolastico and F. Nicotra, Plenum Publishing Corp., New York, NY, 1999, pp. 291-298.

10 O. P. Anderson, A. G. M. Barrett, J. J. Edmunds, S.-I. Hachiya, J. A. Hendrix, K. Horita, J. W. Malecha, C. J. Parkinson and A. VanSickle, Can. J. Chem., 2002, 79, 1562.

11 K. Karisalmi and A. M. P. Koskinen, Synthesis, 2004, 1331.

12 K. Karisalmi and A. M. P. Koskinen, Tetrahedron Lett., 2004, 45, 8245.

13 H. Kigoshi, K. Suenaga, T. Mutou, T. Ishigaki, T. Atsumi, H. Ishiwata, A. Sakakura, T. Ogawa, M. Ojika and K. Yamada, J. Org. Chem., 1996, 61, 5326.

14 I. Paterson, S. D. Blakey and C. J. Cowden, Tetrahedron Lett., 2002, 43, 6005.

15 J. A. Marshall and C. M. Grant, J. Org. Chem., 1999, 64, 696.

16 J. A. Marshall and B. A. Johns, J. Org. Chem., 2000, 65, 1501.

17 K. C. Nicolaou, R. A. Daines, Y. Ogawa and T. K. Chakraborty, J. Am. Chem. Soc., 1988, 110, 4696.

18 D. A. Evans, J. V. Nelson and T. R. Taber, in Topics in Stereochemistry, ed. N. L. Allinger, E. L. Eliel and S. H. Wilen, John Wiley \& Sons, New York, NY, 1982, vol. 13, p. 1.

19 J. Tholander and E. M. Carreira, Helv. Chim. Acta, 2001, 84, 613.
20 K. Karisalmi, K. Rissanen and A. M. P. Koskinen, Org. Biomol. Chem., 2003, 1, 3193.

21 K. Karisalmi, A. M. P. Koskinen, M. Nissinen and K. Rissanen, Tetrahedron, 2003, 59, 1421.

22 F. Sarabia, S. Chammaa and J. Lopez-Herrera, Tetrahedron Lett., 2002, 43, 2961.

23 T. K. Chakraborty, S. Ghosh and S. Dutta, Tetrahedron Lett., 2001, 42, 5085 .

24 Y. Nagao, Y. Hagiwara, T. Kumagai, M. Ochiai, T. Inoue, K. Hashimoto and E. Fujita, J. Org. Chem., 1986, 51, 2391.

25 K. Yasui, Y. Tamura, T. Nakatani, K. Kawada and M. Ohtani, J. Org. Chem., 1995, 60, 7567.

26 M. K. Gurjar, J. T. Henri, Jr, D. S. Bose and A. V. R. Rao, Tetrahedron Lett., 1996, 37, 6615.

27 N. Chida, K. Yamada and S. Ogawa, J. Chem. Soc., Perkin Trans. 1, 1993, 1957.

28 H. Watanabe, H. Watanabe and T. Kitahara, Tetrahedron Lett., 1998, 39, 8313.

29 G. E. Keck, C. E. Knutson and S. A. Wiles, Org. Lett., 2001, 3, 707.

30 L. C. Dias, L. G. Oliveira and M. A. de Sousa, Org. Lett., 2003, 5, 265.

31 Macrolide Antibiotics, ed., S. Omura, Academic Press, Orlando, FL, 1984

32 For leading references: J. Mulzer, H. M. Kirstein, J. Buschmann, C. Lehmann and P. Lugers, J. Am. Chem. Soc., 1991, 113, 910.

33 E. J. Corey, S. Kim, S. Yoo, K. C. Nicolaou, L. S. Melvin, Jr., D. J. Brunelle, J. R. Falck, E. J. Trybulski, R. Lett and P. W. Sheldrake, J. Am. Chem. Soc., 1978, 100, 4620.

34 R. B. Woodward, E. Logusch, K. P. Nambiar, K. Sakan, D. E. Ward, B.-W. Au-Yeung, P. Balaram, L. J. Browne, P. J. Card, C. H. Chen, R. B. Chênevert, A. Fliri, K. Frobel, H.-J. Gais, D. G. Garrat, K. Hayakawa, W. Heggie, D. P. Hesson, D. Hoppe, I. Hoppe, J. A. Hyatt, D. Ikeda, P. A. Jacobi, K. S. Kim, Y. Kobuke, K. Kojima, K. Krowicki, V. J. Lee, T. Leutert, S. Malchenko, J. Martens, R. S. Matthews, B. S. Ong, J. B. Press, T. V. Rajan Babu, G. Rousseau, H. M. Sauter, M. Suzuki, K. Tatsuta, L. M. Tolbert, E. A. Truesdale, I. Uchida, Y. Ueda, T. Uyehara, A. T. Vasella, W. C. Vladuchick, P. A. Wade, R. M. Williams and H. N.-C. Wong, J. Am. Chem. Soc., 1981, 103, 3210.

35 D. A. Evans and A. S. Kim, Tetrahedron Lett., 1997, 38, 53.

36 P. J. Hergenrother, A. Hodgson, A. S. Judd, W.-C. Lee and S. Martin, Angew. Chem., Int. Ed., 2003, 42, 3278. 